\title{
PERANCANGAN ART BOOK TENTANG REDESAIN KARAKTER HANUMAN DALAM BENTUK POPULER SEBAGAI PENGAYAAN KERAGAMAN DALAM PENGEMBANGAN BUDAYA DAN TRADISI
}

\author{
Vinsensius Wahju Jatmiko Wibisono ${ }^{1}$, Aditya Nirwana ${ }^{2}$, Bintang Pramudya P.P \\ Program Studi Desain Komunikasi Visual, Universitas Ma Chung \\ 331610017@student.machung.ac.id, aditya.nirwana@machung.ac.id, \\ bintang.pramudya@machung.ac.id
}

\begin{abstract}
Abstrak
Semakin berkembangnya zaman dan teknologi, maka semakin banyak hal yang dikembangkan para pegiat industri dalam hal apapun. Pengantar tugas akhir ini berjudul Perancangan Art Book tentang Redesain Karakter Hanuman dalam Bentuk Populer Sebagai Pengayaan Keragaman dalam Pengembangan Budaya dan Tradisi. Penelitian ini bertujuan untuk mengenalkan kembali folklor Ramayana, karena masih banyak masyarakat yang kurang mengetahui cerita ini dalam tingkat lapisan umur sekolah sampai dewasa (usia 15 sampai 30 tahun). Oleh karena itu, perancangan ini dibuat untuk mengenalkan kembali kepada masyarakat tentang folklor Ramayana di Indonesia. Cara pengenalan kembali dengan menggunakan media buku ilustrasi. Eksekusi buku ilustrasi ini dikerjakan dengan proses digital melalui perangkat komputer. Perancangan Art Book tentang Redesain Karakter Hanuman ini diharapkan dapat menjadi pengingat kembali akan cerita yang sudah jarang diceritakan pada zaman sekarang ini serta dapat menjadi solusi untuk pengajaran menggunakan media buku ilustrasi dalam kegiatan bercerita dimanapun. Redesain karakter dalam perancangan Art Book juga akan menambah nilai sendiri karena dibuat dalam bentuk populer dengan mengusung tema klasik namun tetap modern. Tujuan dari redesain karakter juga sebagai pengayaan keragaman dalam pengembangan budaya dan tradisi di Indonesia.
\end{abstract}

Kata kunci: Art Book, Redesain Karakter, Folklor
PENDAHULUAN

Pada tahun 2020 dimana masyarakat sudah sangat familiar dengan elektronik, mengakibatkan kurang dikenalnya budaya tradisional Indonesia dikarenakan masyarakat lebih mementingkan hal-hal berbau moderen daripada budayanya sendiri. Banyak sekali budaya tradisional Indonesia yang mulai tidak dapat ditemui atau bahkan menghilang dikarenakan masyarakat tidak tertarik dengan hal-hal yang berbau kuno dan tidak modern. Salah satu budaya tradisional yang hilang atau sedikit masyarakat milenial yang tahu adalah folklor. Folklor menurut (Saleh, 2012) adalah dimensi masa lampau yang bisa dijadikan sebagai media pembelajaran yang terbaik untuk melangkah di masa depan. Dalam arti ini folklor dalam pendidikan menjadi resolusi untuk mencerminkan dan menjaga kearifan lokal. Sedangkan pengertian folklor menurut Saleh dan dengan kenyataan yang kita hadapi saat ini itu berbanding terbalik. Berbanding terbalik dikarenakan di zaman milenial saat ini, penyampaian folklor secara lisan dari generasi ke generasi jarang atau bahkan tidak dapat ditemui. Seperti yang sudah diungkapkan oleh Saleh bahwa folklor dapat dijadikan media pembelajaran yang terbaik untuk melangkah di masa depan. Salah satu folklor yang tidak asing didengar oleh masyarakat Indonesia yaitu folklor

Ramayana

\section{TINJAUAN PUSTAKA}

\section{Jurnal Ilmiah}

Studi pustaka yang pertama dilakukan terhadap artikel jurnal penelitian yang berjudul Perancangan Buku Panduan Membuat Desain Karakter Fiksi Dua Dimensi secara Digital, oleh Ruyattman dkk. (2013). Perancangan ini bertujuan untuk mendapatkan rancangan pembuatan karakter fiksi yang menarik dimana dapat bersaing dalam industri kreatif global. Dengan metode deskriptif kualitatif yang terdiri dari Metode observasi, dan dokumentasi, diperoleh kesimpulan (sintesa) : 1) Gagasan perancangan desain karakter fiksi dua dimensi ini adalah untuk membuat desain karakter fiksi yang menarik yang dapat bersaing dalam industri kreatif global 2) Dalam buku panduan perancangan karakter fiksi dua dimensi, memiliki pembahasan berfokus pada desain karakter yang terdiri dari

8 poin, yaitu: Desain, Karakter Fiksi, Secara Digital, Desain Karakter Fiksi, Konsep Perancangan, Target Audience, Gaya Visual/Grafis, Teknik

Character, Folklore. 
Visualisasi. Artikel ini memberikan masukan dalam perancangan ini berupa 1) Metode dalam perancangan karakter fiksi; 2) Poin-poin penting yang dapat membantu menciptakan karakter fiksi yang berdaya saing.

\section{Buku Referensi}

Desain Karakter merupakan aspek yang penting untuk menceritakan kisah dan membangkitkan sebuah respon emosional di dalam cerita dan permainan (Adams, 2007, p.149). Dalam menciptakan sebuah desain karakter yang baik, poin pertama yang harus diperhatikan adalah arketipe (archetype). Arketipe mewakili kepribadian dari karakter yang dapat diumpamakan sebagai manusia. Ada beragam arketipe yang berbeda-beda, tetapi terdapat beberapa jenis yang umum dan selalu digunakan berulang kali. Carl Jung mengembangkan banyak arketipe, namun yang sering digunakan di dalam sebuah cerita yaitu pahlawan, penjahat, si bodoh, anima/animus, pembimbing, penipu. Arketipe ini dapat ditemukan di dalam mitologi dan sastra yang dimana telah digunakan selama berabad-abad untuk menceritakan sebuah cerita, khususnya cerita petualangan epik. (Krawczyk, 2006, p.108). Arketipe sendiri dianggap sebagai cetakan atau model asli dari manusia, sifat, ataupun perilaku yang kita sebagai manusia berharap agar dapat diteladani dan dicontoh. Tak dapat dipungkiri juga bahwa penggunaan berbagai jenis arketipe sendiri sudah ada sejak dahulu, terbukti dapat ditemukan mulai dari karya-karya Shakespeare. Selain penggunaan arketipe, unsur penting yang kedua yaitu cerita. Cerita sendiri untuk berguna untuk pengembangan serta mengenalkan karakter dengan lebih jelas.

Selain menggunakan buku referensi tentang pembuatan karakter, dalam perancangan ini menggunakan buku tentang wayang purwa dikarenakan sosok tokoh Hanuman sendiri terkenal di masyarakat Indonesia melalui penampilan wayang purwa. Wayang merupakan istilah bahasa Jawa yang dapat dimaknai sebagai "bayangan" dikarenakan tampilan yang disajikan hanya berupa bayangan saja. Wayang juga merupakan seni tradisi dan juga warisan dari nenek moyang yang merupakan dasar dari budaya timur. Cerita yang disajikan oleh wayang sendiri mengandung kearifan lokal dan mengandung nilai-nilai dan ajaran yang bersifat positif seperti kebijaksanaan serta keluhuran budi pekerti.

Wayang selain dijadikan sebagai media informasi, juga merupakan media hiburan. Seringkali pertunjukan wayang diisi dengan Campursari dan lawak. Namun meskipun diisi dengan lawakan, tujuan pertunjukan wayang sendiri tetap berpegang teguh sebagai tontonan dan tuntunan. Wayang juga dapat dipakai sebagai sarana pendidikan khususnya pendidikan mental dan watak. Dalam hal pendidikan, dapat ditunjukan dari cerita wayang yang terdapat tentang unsur kebenaran, keadilan, kejujuran, ketaatan, kesetiaan, kepahlawanan, dan spiritual. Unsur pendidikan watak dalam pagelaran wayang juga tergambar pada masing-masing wayang sebagai perwujudan watak dan sifat manusia. Sebagian besar watak manusia digambarkan melalui bentuk raut wajah yang ada pada wayang seperti pada mata, hidung, mulut, dan warna wayang dapat mengekspresikan perwatakan dan sifat wayang.

\section{METODE PERANCANGAN}

Dalam perancangan karakter Hanuman ini, metode perancangan karakter yang digunakan adalah metode dari Bryan Tillman (2011) yang bukunya berjudul Creative Character Design. Bryan Tillman menjelaskan metode perancangan karakter diawali dengan menentukan jenis karakter atau arketipe apa yang ingin digunakan. Arketipe merupakan cetakan atau model asli dari manusia yang terdiri dari sifat, ataupun perilaku yang berharap untuk dapat disalin dan ditiru. Dalam Arketipe terbagi menjadi sisi yang baik dan jahat. Dalam bukunya juga, Tillman (2011:12-23) menjelaskan bahwa terdapat 6 jenis arketipe karakter yang sering digunakan atau bisa disebut dengan populer, yaitu : 1) The Hero; 2) The Shadow; 3) The Fool; 4) The Anima/Animus; 5) The Mentor; 6) The Trickster. Masing-masing arketipe tersebut dijelaskan definisinya. Yang pertama The Hero yaitu merupakan sosok yang berjiwa sosial yang tinggi, peduli terhadap orang yang membutuhkan, dan merupakan sosok yang berani. Biasanya The Hero ini merupakan sosok protagonis yang memiliki sifat-sifat baik. Adapula The Shadow dimana merupakan sosok karakter yang misterius, kejam, jahat, dan tidak menyenangkan yang biasanya The Shadow ini merupakan sosok antagonis. The Fool merupakan sosok dalam cerita yang dalam keadaan bingung yang justru membuat semua orang mau tidak mau berada dalam situasi yang tidak diinginkan. The Fool di dalam cerita biasanya menguji karakter utama. The Anima/Animus terbagi menjadi dua, yaitu Anima dan Animus. Anima yaitu pasangan wanita untuk pria sedangkan animus merupakan mitra pria untuk wanita. Selanjutnya The Mentor merupakan sosok yang memiliki peran penting agar protagonis menyadari po-tensi yang dimilikinya. Biasanya The Mentor digambarkan sebagai pria ataupun wanita tua. Hal tersebut tidak sembarangan, penggambaran berupa orangtua karena biasanya identik dengan kebijaksanaan. Sedangkan yang terakhir yaitu The Trickster merupakan sosok yang bisa memberikan dorongan perubahan. The Trickster bisa berada pada sisi yang baik ataupun sisi yang jahat. Diantara kedua situasi tersebut, The Trickster biasanya berusaha untuk mengarahkan cerita ke arah yang menguntungkan baginya. The Trickster juga biasanya menyebabkan keraguan bagi karakter protagonis.

Setelah menentukan arketipe karakter apa yang dipilih, langkah selanjutnya yaitu melengkapi informasi terkait karakter dengan $5 \mathrm{~W}+1 \mathrm{H}$, yaitu: 1) Who? (membeberkan informasi mengenai karakter); 2) What? (Apa yang menjadi motivasi karakter untuk melakukan aksinya); 3) When? (Kapan cerita karakter tersebut dialami); 4) Where? (Dimana cerita tersebut terjadi); 5) Why? (Mengapa karakter tersebut menjadi termotivasi untuk melaksanakan aksinya); 6) How? (Bagaimana karakter tersebut melaksanakan aksinya?). Selanjutnya yaitu membuat Character development worksheet yang mencakup informasi-informasi inti dari karakter. Informasi tersebut terdiri dari : 1) Basic Statistics; 2) Distinguishing Features; 3) Social Characteristics; 4) Attributes dan Attitudes; 5) Emotional Characteristics; dan 6) Spiritual Characteristics.

Adanya data sangat diperlukan dalam menyusun sebuah konsep

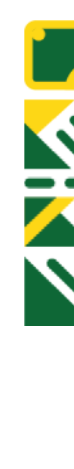


karakter. Data yang diperoleh pun didapat dengan teknik pengumpulan data kualitatif, observasi, dan studi kepustakaan. Observasi atau pengamatan dilakukan dengan melihat wayang purwa, dan tiap-tiap gambar Hanuman untuk mendapatkan data berupa bentuk secara visual, dan atribut fisik tokoh wayang yang akan dirancang. Di samping itu pengamatan juga dilakukan terhadap dokumenter pementasan Ramayana untuk mendapatkan data berupa atribut serta watak terhadap karakter yang akan dirancang. Adapun studi kepustakaan dilakukan terhadap kisah asli Ramayana karya Gopalachari. Dari pemaparan metode perancangan, dapat disusun bagan alur perancangan seperti gambar di bawah.

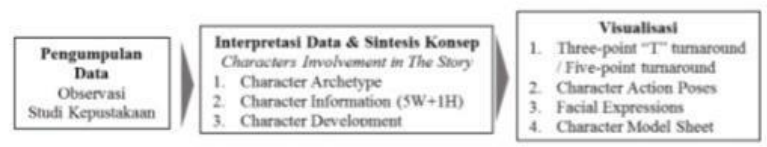

Gambar 1. Bagan Alur Perancangan

\section{Pengumpulan Data Observasi}

Observasi yang digunakan dalam perancangan ini adalah observasi pasif dimana penulis mengamati terkait trend atau hal yang diminati oleh masyarakat khususnya masyarakat milenial. Observasi dilakukan agar penulis mengetahui dengan pasti mengenai hal apa saja yang harus dilakukan agar karakter yang diciptakan diminati oleh masyarakat milenial

\section{Studi Pustaka}

Selain menggunakan metode observasi, dalam perancangan ini penulis melakukan studi pustaka yang dimana mendapatkan data tentang panduan mengenai desain karakter serta cerita folklor Ramayana dan karakteristik karakter yang terdapat di dalam cerita folklor tersebut khususnya Hanuman. Dari beberapa hal tersebut maka mendapatkan data dan kemudian diinterpretasikan atau digunakan untuk mengisi beberapa sheet yang tersedia meliputi Character Information dan Character Development Worksheet.

\section{Character Information}

Berdasarkan tokoh Hanuman, dan juga observasi terhadap sifat dan wataknya serta wujud visualnya, dapat dijabarkan mengenai character information karakter Hanuman yang terdiri dari 1) Who?; 2) What?; 3) When?; 4) Where?; 5) Why?; 6) How? Berikut merupakan contoh tabel mengenai character information.

Tabel 1. Character Information

\begin{tabular}{|l|l|}
\hline \multirow{2}{*}{1.} & Who? (Siapa?) \\
\cline { 2 - 2 } & \\
\hline \multirow{2}{*}{2.} & $\begin{array}{l}\text { What? (Apa yang dilakukan karakter } \\
\text { tersebut dalam cerita) }\end{array}$ \\
\cline { 2 - 2 } & \\
\hline
\end{tabular}

\begin{tabular}{|l|l|}
\hline \multirow{2}{*}{3.} & $\begin{array}{l}\text { When? (Kapan setting waktu dalam } \\
\text { cerita tersebut?) }\end{array}$ \\
\cline { 2 - 2 } & \\
\hline \multirow{2}{*}{4.} & $\begin{array}{l}\text { Where? (Di mana setting tempat } \\
\text { dalam cerita tersebut?) }\end{array}$ \\
\cline { 2 - 2 } & \\
\hline \multirow{2}{*}{5.} & $\begin{array}{l}\text { Why? (Hal apa yang menjadi dasar } \\
\text { karakter melakukan tindakan dan } \\
\text { upaya dalam cerita?) }\end{array}$ \\
\cline { 2 - 2 } & \\
\hline \multirow{2}{*}{6.} & How? (Bagaimana caranya?) \\
\cline { 2 - 2 } & \\
\hline
\end{tabular}

Tabel 2. Character Development Worksheet

\begin{tabular}{|c|c|}
\hline \multicolumn{2}{|c|}{ iasic Statistics } \\
\hline Name & \\
\hline Real Name & \\
\hline Alias & \\
\hline Age & \\
\hline Height & \\
\hline Weight & \\
\hline Sex & \\
\hline Race & \\
\hline Eye Color & \\
\hline Hair & \\
\hline Nationality & \\
\hline Skin color & \\
\hline Shape offace & \\
\hline
\end{tabular}

\begin{tabular}{|c|c|}
\hline \multicolumn{2}{|c|}{ Social Characteristics } \\
\hline Hometown & \\
\hline Current & \\
Residence & \\
\hline Occupation & \\
\hline Talents & \\
\hline Family Status & \\
\hline
\end{tabular}

\begin{tabular}{|c|c|}
\hline \multicolumn{2}{|c|}{ Emotional Characteristics } \\
\hline Introvert/Extrovert? & \\
\hline Fear & \\
\hline Motivation & \\
\hline Happiness & \\
\hline Relationship & \\
\hline
\end{tabular}

\begin{tabular}{|c|c|}
\hline \multicolumn{2}{|c|}{ Distinguishing Features } \\
\hline Clothing & \\
\hline Mannerisms & \\
\hline Habits & \\
\hline Health & \\
\hline
\end{tabular}

\begin{tabular}{l|l} 
FAKULtAS \\
SAINS \& TEKNOLOGI \\
UNIVERSITAS MA CHUNG
\end{tabular} 


\begin{tabular}{|c|l|}
\hline Hobbies & \\
\hline Favorite & \\
Sayings & \\
\hline Disabilities & \\
\hline Greatest Flaw & \\
\hline Best Quality & \\
\hline
\end{tabular}

\begin{tabular}{|c|c|}
\hline \multicolumn{2}{|c|}{ Attributes and Attitudes } \\
\hline $\begin{array}{c}\text { Educational } \\
\text { Background }\end{array}$ & \\
\hline $\begin{array}{c}\text { Intelligence } \\
\text { Level }\end{array}$ & \\
\hline $\begin{array}{c}\text { Short-term } \\
\text { Goal }\end{array}$ & \\
\hline Long-term & \\
Goal & \\
\hline Self-esteem & \\
\hline Confidence & \\
\hline Emotional & \\
state & \\
\hline
\end{tabular}

\begin{tabular}{|c|c|}
\hline \multicolumn{2}{|c|}{ Spiritual Characteristics } \\
\hline Does the & \\
character & \\
believe in a & \\
supreme & \\
being? & \\
\hline
\end{tabular}

\section{HASIL DAN PEMBAHASAN}

Pada zaman dahulu terdapat sebuah kerajaan yang terletak di utara Sungai Gangga bernama Kosala yang memiliki pemimpin seorang raja bernama Dasarata. Dasarata memiliki tiga orang istri yaitu Kausalya, Kaikeyi, dan Sumitra. Ketiga istrinya tersebut melahirkan empat putra yang bernama Rama, Bharata, Laksmana, dan

Satruguna.

Salah satu anaknya yang bernama Rama kemudian berguru bersama Wiswamitra setelah membantu beliau mengusir para raksasa yang sering mengganggu para Resi. Setelah menjadi murid Wiswamitra dan mengembara, di tengah-tengah perjalanan Ramapun mengikuti sebuah sayembara pengangkatan busur yang menawarkan hadiah berupa pernikahan dengan Sinta. Ramapun berhasil memenangkan sayembara tersebut dan kemudian menikah dengan Sinta.

Setelah Rama selesai berguru dan mengembara bersama Wiswamitra, dia kembali di desa asalnya yang disambut bahagia oleh Dasarata dimana sang raja berpikiran akan memberikan kekuasaan raja untuk Rama. Seluruh keluarga dan masyarakat desapun menyetujui hal tersebut, namun salah satu istri beliau yang bernama Kaikeyi menolak penobatan Rama sebagai raja baru. Hal tersebut berujung pada pengasingan Rama yang ditemani oleh Sinta dan
Laksmana yang selalu setia bersamanya.

Ditengah-tengah pengasingan tersebut terdapat insiden buruk yaitu diculiknya Sinta oleh seorang raksasa bernama Rahwana sang penguasa Alengka. Hal tersebut dipicu saat Sinta melihat seekor rusa berbulu indah yang kemudian menyuruh Rama untuk menangkapnya. Tapi sayangnya rusa tersebut ternyata hanya berupa pancingan agar Rama jauh dari sisi Sinta yang akhirnya berhasil diculiknya Sinta oleh Rahwana.

Rama dan Laksemana pun akhirnya meminta bantuan kepada Sugriwa dan Hanuman yang keduanya merupakan sosok wanara yang sangat sakti. Permintaan tolong Rama kepada wanara ini pun membuahkan hasil yaitu berhasil diselamatkannya Sinta serta Rama pun berhasil menjadi Raja dan akhirnya hidup bahagia bersama.

\section{Karakter 1.}

Hanuman

a) Character Infromation

Tabel 3. Hanuman Character Information

\begin{tabular}{|c|c|}
\hline \multirow[b]{2}{*}{1.} & Who? (Siapa?) \\
\hline & Hanuman yang merupakan wanara \\
\hline \multirow[t]{2}{*}{2.} & $\begin{array}{l}\text { What? (Apa yang dilakukan karakter } \\
\text { tersebut dalam cerita) }\end{array}$ \\
\hline & $\begin{array}{l}\text { Melakukan penyelamatan Sinta. Melawan } \\
\text { Rahwana dan Indrajit }\end{array}$ \\
\hline \multirow[t]{2}{*}{3.} & $\begin{array}{l}\text { When? (Kapan setting waktu dalam cerita } \\
\text { tersebut?) }\end{array}$ \\
\hline & Saat Sinta diculik Rahwana \\
\hline \multirow[t]{2}{*}{4.} & $\begin{array}{l}\text { Where? (Di mana setting tempat dalam cerita } \\
\text { tersebut?) }\end{array}$ \\
\hline & Di kerajaan Alengka \\
\hline \multirow[t]{2}{*}{5.} & $\begin{array}{l}\text { Why? (Hal apa yang menjadi dasar karakter } \\
\text { melakukan tindakan dan upaya dalam } \\
\text { cerita?) }\end{array}$ \\
\hline & $\begin{array}{l}\text { Karena hal yang sudah dilakukan Rahwana } \\
\text { salah serta Rama merupakan seseorang } \\
\text { yang dapat dipercaya dan merupakan calon } \\
\text { raja. }\end{array}$ \\
\hline \multirow[b]{2}{*}{6.} & How? (Bagaimana caranya?) \\
\hline & $\begin{array}{l}\text { Dengan melawan Rahwana serta membakar } \\
\text { kerajaan Alengka dan membebaskan Sinta }\end{array}$ \\
\hline
\end{tabular}

b) Character Development Worksheet

Tabel 4. Hanuman Character Development Worksheet

\begin{tabular}{|l|c|}
\hline \multicolumn{2}{|c|}{ Basic Statistics } \\
\hline Name & Hanuman \\
\hline
\end{tabular}




\begin{tabular}{|c|c|}
\hline Real Name & $\begin{array}{c}\text { Maruti, Ramadayapati, } \\
\text { Bayutanaya, Kapiwara, } \\
\text { Anjaniputra, Bayu-siwi, } \\
\text { Guru-putra, Yudawisma, } \\
\text { Maruta, Prabancana, Resi } \\
\text { Mayang-kara. }\end{array}$ \\
\hline Alias & 300 tahun \\
\hline Age & 2 meter \\
\hline Height & \\
\hline
\end{tabular}

\begin{tabular}{|c|c|}
\hline \multicolumn{2}{|c|}{ Social Characteristics } \\
\hline Hometown & Kendhalisada \\
\hline $\begin{array}{c}\text { Current } \\
\text { Residence }\end{array}$ & Kendhalisada \\
\hline Occupation & Indonesia \\
\hline Talents & Berjalan seperti angin \\
\hline Family Status & - \\
\hline
\end{tabular}

\begin{tabular}{|c|c|}
\hline $\begin{array}{c}\text { Does the } \\
\text { character } \\
\text { believe in a } \\
\text { supreme } \\
\text { being? }\end{array}$ \\
\hline Weight & Iya \\
\hline Sex & Pria \\
\hline Race & Wanara \\
\hline Eye Color & Merah \\
\hline Hair & Putih keabu-abuan \\
\hline Nationality & Indonesia \\
\hline Skin color & Coklat tua \\
\hline Shape offace & Oval \\
\hline
\end{tabular}

\section{Format Perancangan}

\section{Media}

\begin{tabular}{|c|c|}
\hline \multicolumn{2}{|c|}{ Emotional Characteristics } \\
\hline Introvert/Extrovert? & Introvert \\
\hline Fear & - \\
\hline Motivation & Menyelematkan Sinta \\
\hline Happiness & $\begin{array}{c}\text { Menolong orang } \\
\text { yang membutuhkan }\end{array}$ \\
\hline Relationship & Lajang \\
\hline
\end{tabular}

\begin{tabular}{|c|c|}
\hline \multicolumn{2}{|c|}{ Distinguishing Features } \\
\hline Clothing & $\begin{array}{c}\text { Gabungan modern dan } \\
\text { tradisional }\end{array}$ \\
\hline Mannerisms & $\begin{array}{c}\text { Jawa klasik campur } \\
\text { modern }\end{array}$ \\
\hline Habits & Melakukan hal baik \\
\hline Health & Baik \\
\hline Hobbies & Menolong \\
\hline Favorite Sayings & $\begin{array}{c}\text { Berbuatlah baik kepada } \\
\text { semua orang }\end{array}$ \\
\hline Disabilities & - \\
\hline Greatest Flaw & - \\
\hline Best Quality & $\begin{array}{c}\text { Kekuatan supernatural, } \\
\text { bela diri }\end{array}$ \\
\hline
\end{tabular}

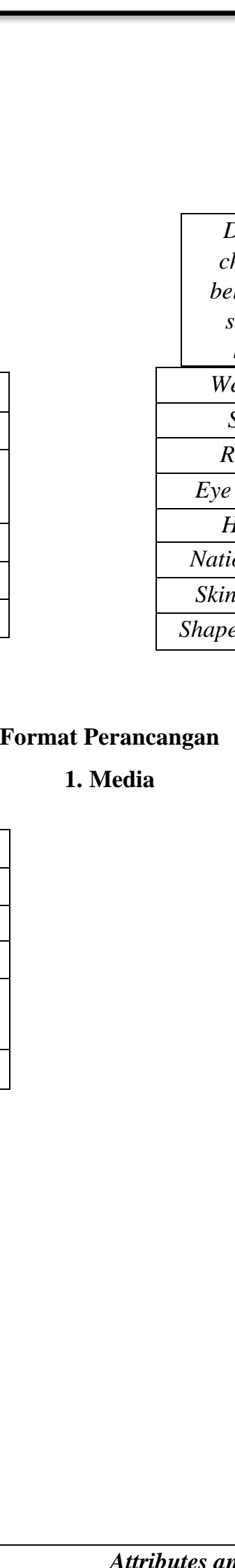

Attributes and Attitudes

\begin{tabular}{|c|c|}
\hline \multicolumn{2}{|c|}{ Attributes and Attitudes } \\
\hline $\begin{array}{c}\text { Educational } \\
\text { Background }\end{array}$ & $\begin{array}{c}\text { Murid dari Sugriwa yang } \\
\text { merupakan Raja Kera }\end{array}$ \\
\hline $\begin{array}{c}\text { Intelligence } \\
\text { Level }\end{array}$ & Diatas rata-rata \\
\hline
\end{tabular}




\begin{tabular}{|c|c|c|c|}
\hline \multirow[t]{5}{*}{ Media yang digunakan } & $\begin{array}{c}\text { Short-term } \\
\text { Goal }\end{array}$ & Menyelamatkan Sinta & \multirow{5}{*}{$\begin{array}{l}\text { dalam pembuatan karya } \\
\text { ini adalah buku, beberapa } \\
\text { merchandiser seperti } \\
\text { totebag, kaos dan topi, } \\
\text { media sosial seperti } \\
\text { instagram, facebook. } \\
\text { Penggunaan media } \\
\text { artbook sendiri ditujukan }\end{array}$} \\
\hline & Long-term Goal & $\begin{array}{l}\text { Mendampingi Rama } \\
\text { sampai menjadi Raja }\end{array}$ & \\
\hline & Self-esteem & Tinggi & \\
\hline & Confidence & Rata-rata & \\
\hline & Emotional state & Baik dan Sabar & \\
\hline
\end{tabular}

mengenal cerita yang disampaikan tanpa mengalami rasa bosan dikarenakan terdapat gambar ilustrasi di dalamnya. Isi dari artbook yaitu cerita singkat tentang epos Ramayana dan juga ilustrasi karakter-karakter dalam epos tersebut yang sudah di redesain beserta penjelasanpenjelasannya. Penggunaan beberapa merchandaise sendiri juga untuk mengenalkan karya kekhalayak umum secara langsung dan penggunaan media sosial bisa dijadikan sebagai media promosi dikarenakan mengingat majunya jaman saat ini membuat media sosial dapat diakses dengan mudah oleh siapapun tanpa mengenal tempat dan waktu.

\section{Visual}

Visual merupakan hal yang penting dalam suatu artbook. Visual yang ditampilkan yaitu visual yang semi realis agar dapat menghibur pembaca tanpa menghilangkan unsur kenyataan (realisnya).

\section{Pemilihan Tipografi}

\section{Gambar 2. Tipografi pada Art Book}

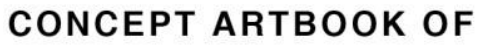 RAMAYANA}

C H A R A T E R D E S I G N

Tipografi yang digunakan dalam perancangan Art Book ini adalah Helvetica. Font ini sendiri merupakan typeface yang berjenis sans serif berlandaskan pada prinsip Swiss style yang typefacenya mempunyai bentuk dan tingkat kejelasan yang nyata. Maksud dari nyata sendiri yaitu font yang bersih, tidak ada makna intrinsik, dan juga mempunyai tingkat keterbacaan yang tinggi. Alasan menggunakan font Helvetica sendiri juga dikarenakan menggambarkan sikap modernisme yang kuat.

Spiritual Characteristics

\section{Palet Warna Karakter Hanuman}

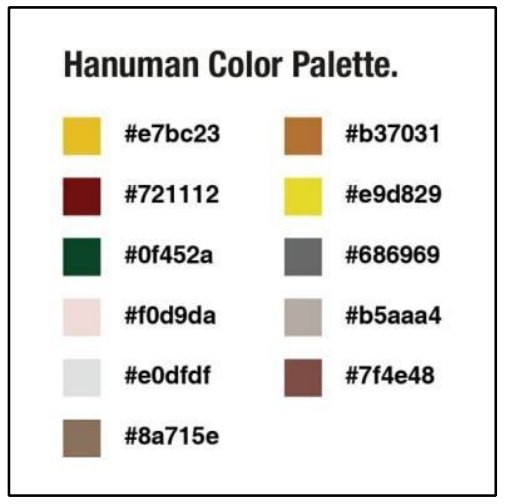

1) Rough Sketch Hanuman

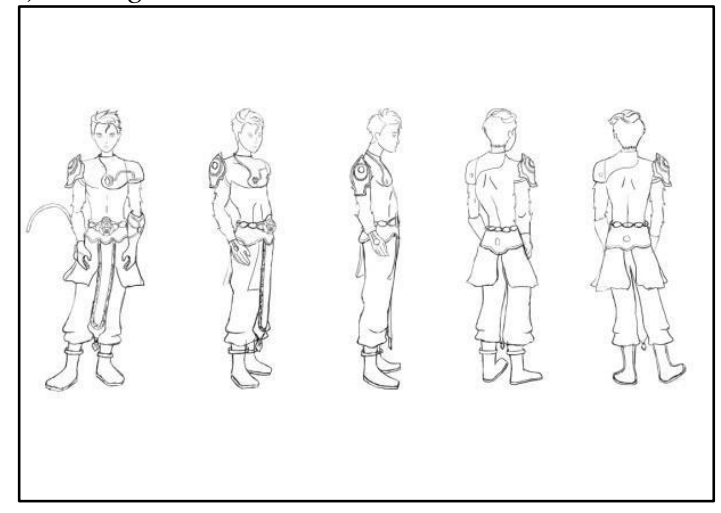




\section{Gambar 3. Palet Warna Karakter Hanuman}

\section{Gambar 4. Rough Sketch Hanuman} Penulis)

Hanuman yang disajikan disini mempunyai warna kulit coklat dan bulu yang berwarna putih. Penggunaan kedua warna tersebut untuk tubuh Hanuman didukung dengan arti atau makna psikologis yang ada, yang pertama yaitu warna coklat yang mempunyai makna kehangatan serta dapat dipercaya. Sedangkan warna putih memiliki makna kesucian dan keyakinan. Sosok Hanuman yang diredesain tetap menyajikan unsur visual monyet. Adapula armor yang dikenakan berwarna emas karena memiliki makna aktif dan dinamis serta kesuksesan. Terdapat juga warna merah yang memiliki makna enerjik, kekuatan, serta percaya diri. Warna hijau juga digunakan pada bagian celana juga memiliki arti yaitu ketenangan, ketabahan dan kedamaian. Penggunaan warna hijau yang merupakan warna dingin inilah yang membantu agar karakter terlihat Gambar 5. Rough Sketch Hanuman

stabil mengingat mayoritas warna atribut yang dikenakan

Data Penulis)

\section{Pemilihan Gaya Gambar}

Pemilihan gaya gambar pada karya Art Book ini adalah semi realism. Hal tersebut ditunjukkan dari anatomi yang masih terlihat jelas menyerupai aslinya (manusia asli) meskipun muka dari karakter sendiri tidak nyata. Jadi semi realism sendiri merupakan gabungan gaya gambar lucu dan gambar realis yang bertujuan agar menghibur pembaca dari segi tampilan yang lebih menarik tanpa menghilangkan unsur nyatanya.

\section{IMPLEMENTASI DAN UJI COBA}

\section{Rough Sketch}

(Sumber:
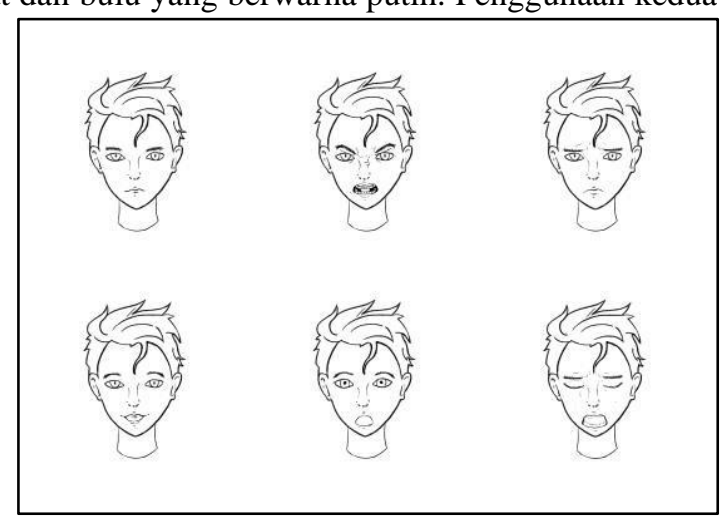

(Sumber: Data

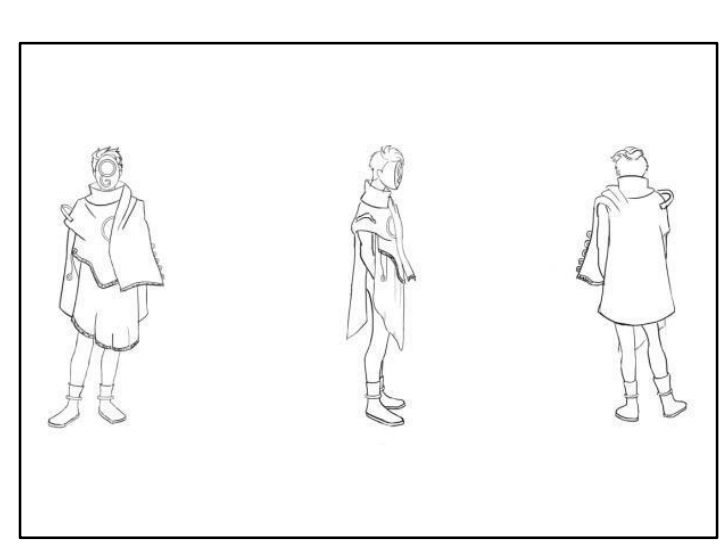

Rough Sketch disini dibagi menjadi dua yaitu rough sketch (Sumber: Data Penulis) sebelum dan sesudah dilakukan perbaikan. Bagian pertama yaitu merupakan rough sketch hasil awal dimana masih merupakan konsep awal kreator, dan yang kedua yaitu rough sketch sesudah dilakukan perbaikan. Berikut merupakan salah satu lampiran rough sketch dari karakterkarakter yang sudah didesain yaitu 1) Hanuman; 2) Rama; 3) Sinta; 4) Rahwana; 5) Indrajit:

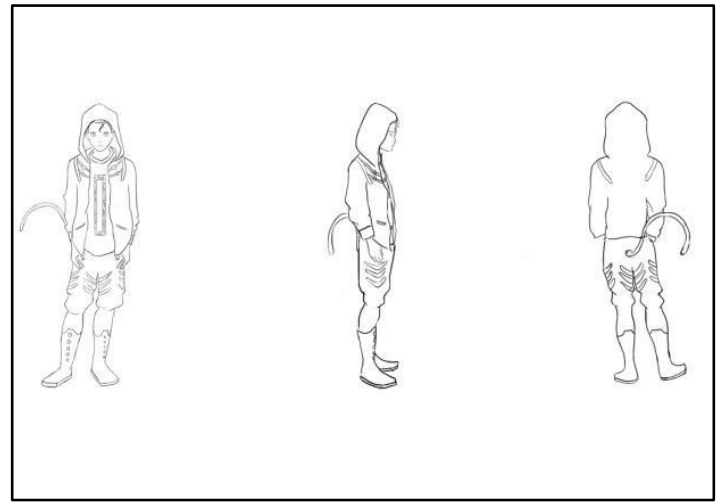

Gambar 7. Rough Sketch Hanuman (Sumber: Data Penulis)

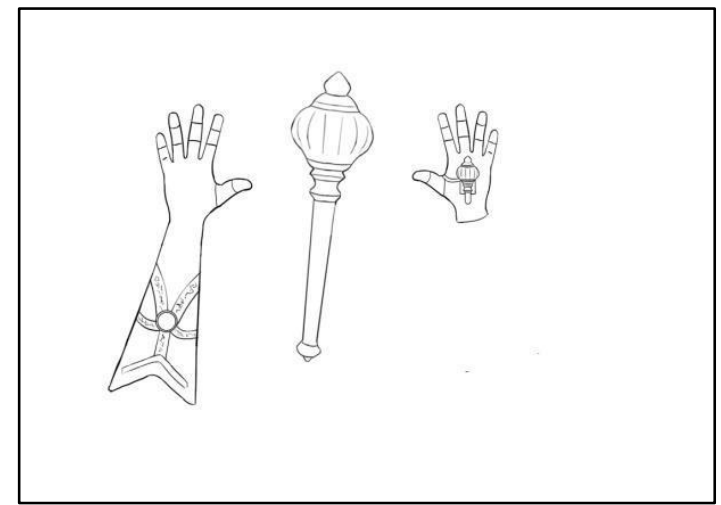

Gambar 10. Rough Sketch Hanuman (Sumber: Data Penulis) 


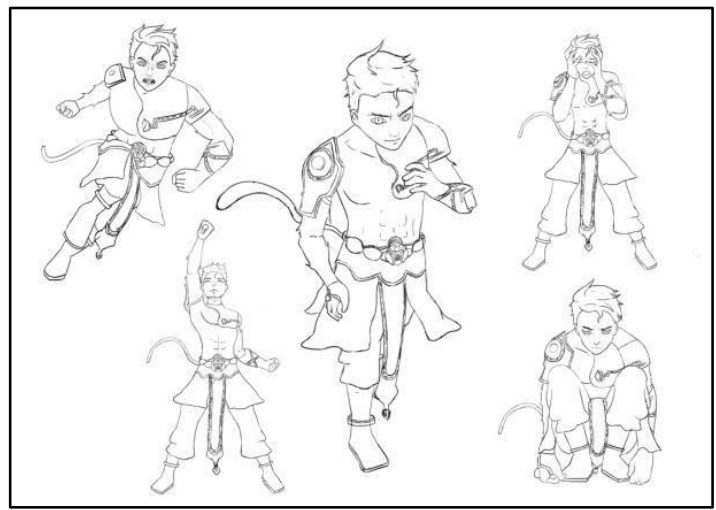

Gambar 8. Rough Sketch Hanuman (Sumber: Data Penulis)

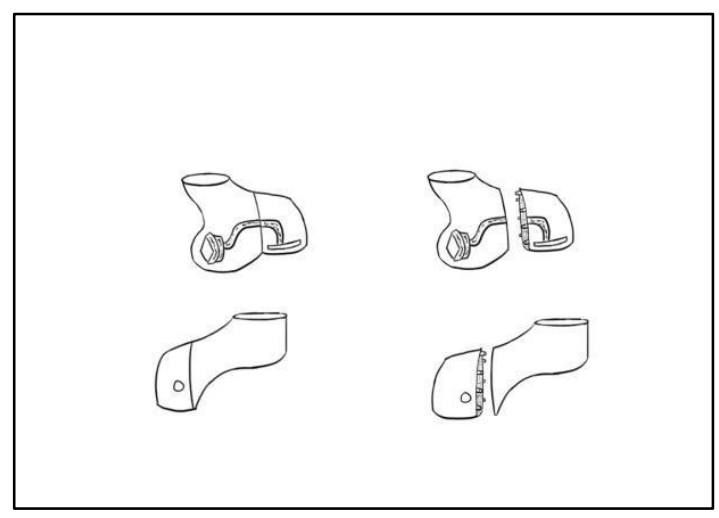

Gambar 9. Rough Sketch Hanuman (Sumber: Data Penulis)
2) Rough Sketch Rama

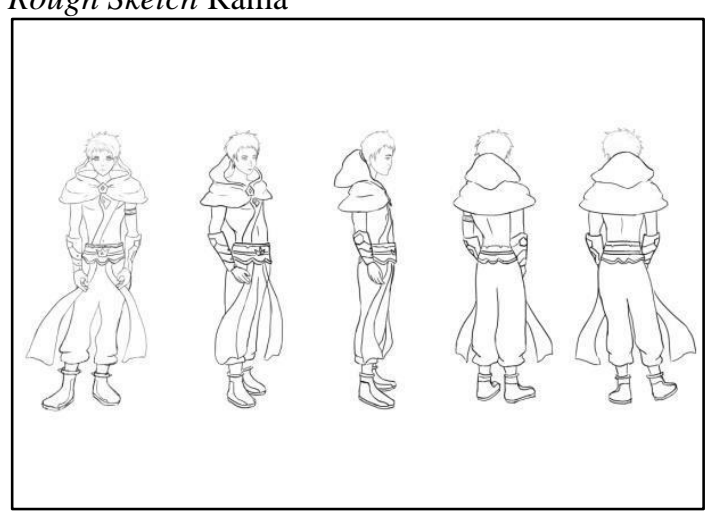

Gambar 11. Rough Sketch Rama (Sumber: Data Penulis)

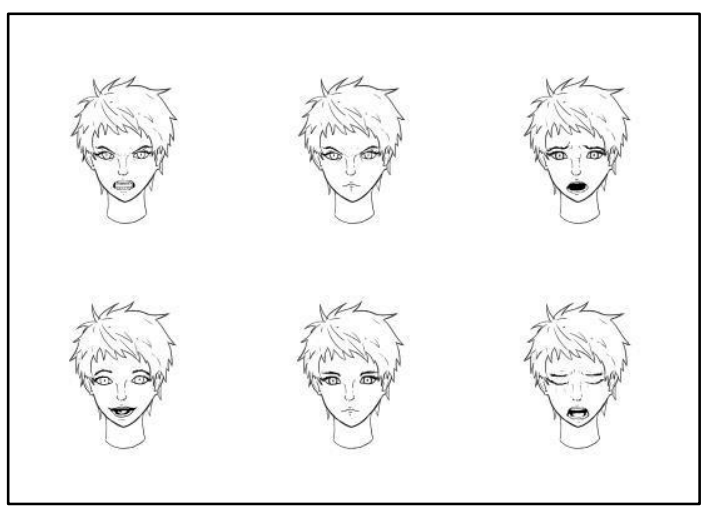

Gambar 12. Rough Sketch Rama (Sumber: Data Penulis) 

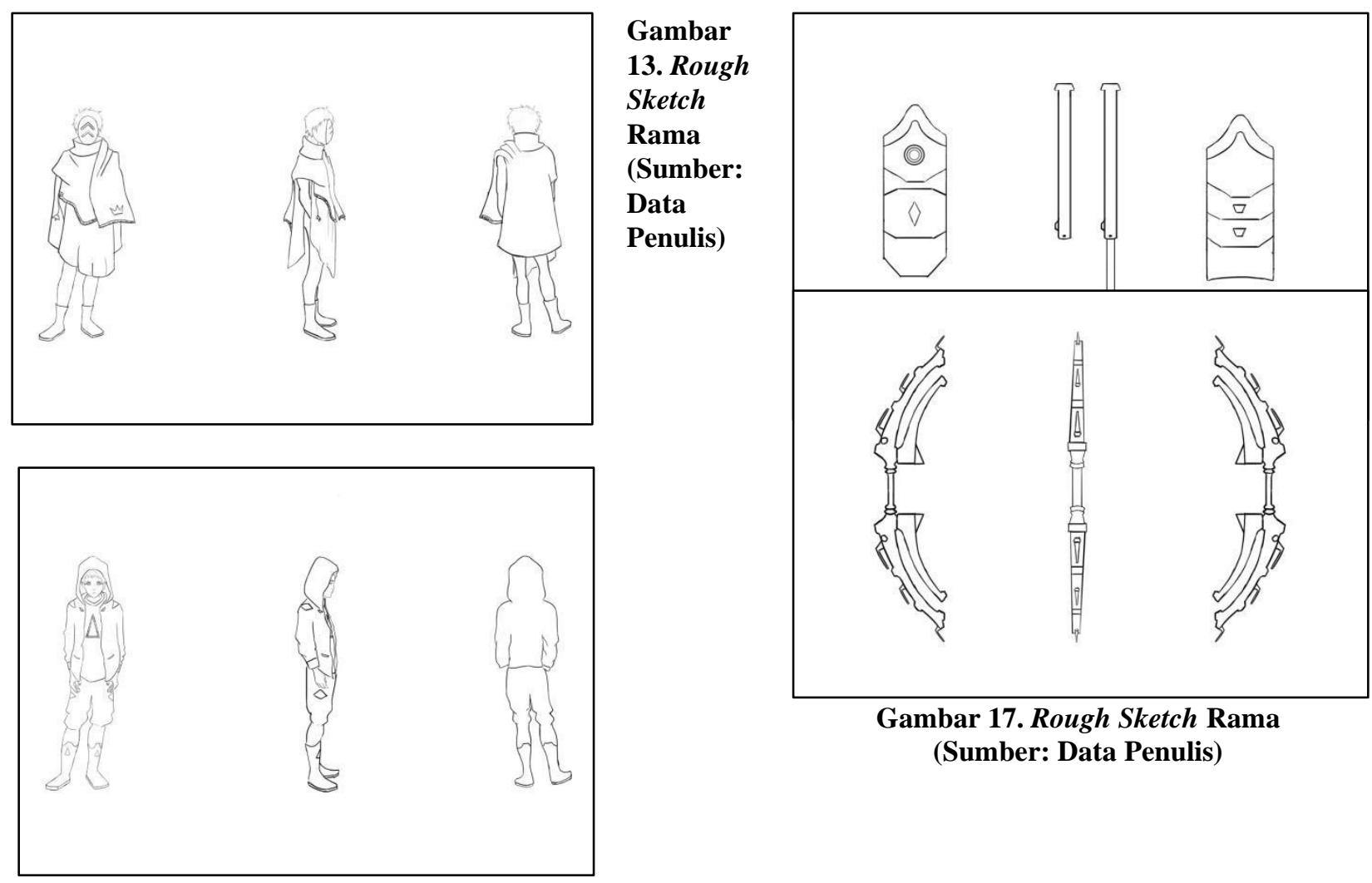

Gambar 17. Rough Sketch Rama (Sumber: Data Penulis)

Gambar 14. Rough Sketch Rama (Sumber: Data Penulis)

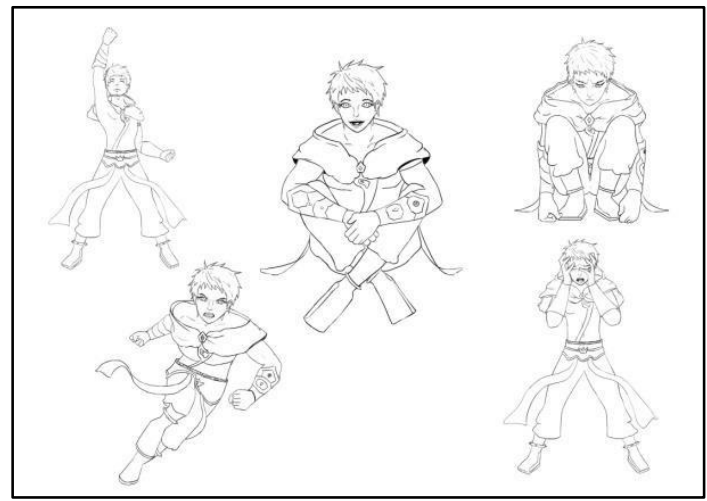

3) Rough Sketch Sinta

Gambar 15. Rough Sketch Rama (Sumber: Data Penulis)

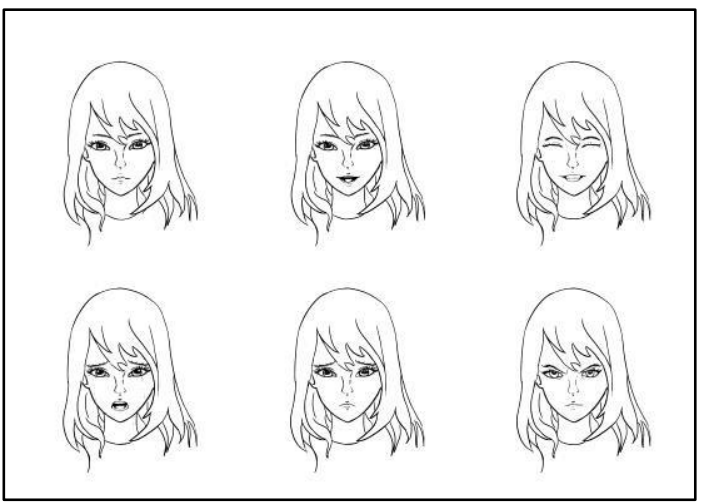

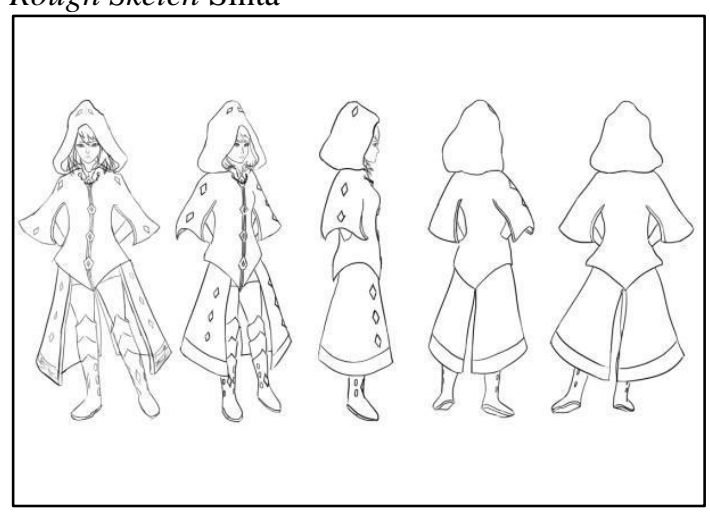

Gambar 18. Rough Sketch Sinta (Sumber: Data Penulis)

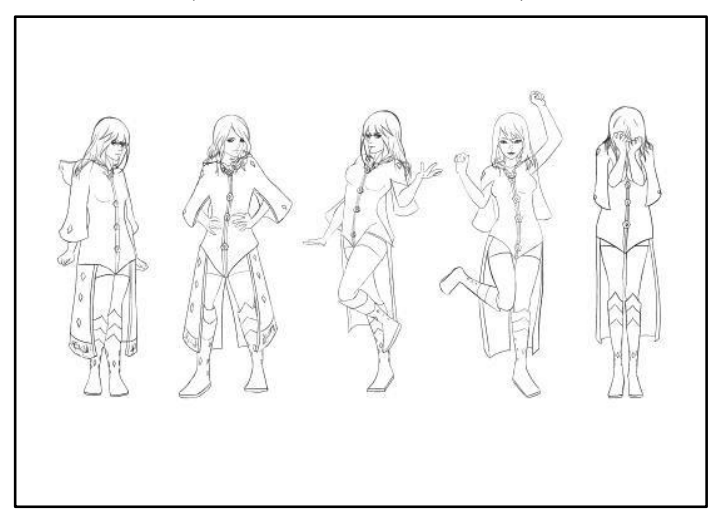


Gambar 19. Rough Sketch Sinta Gambar 22. Rough Sketch Sinta (Sumber: Data Penulis) (Sumber: Data Penulis)

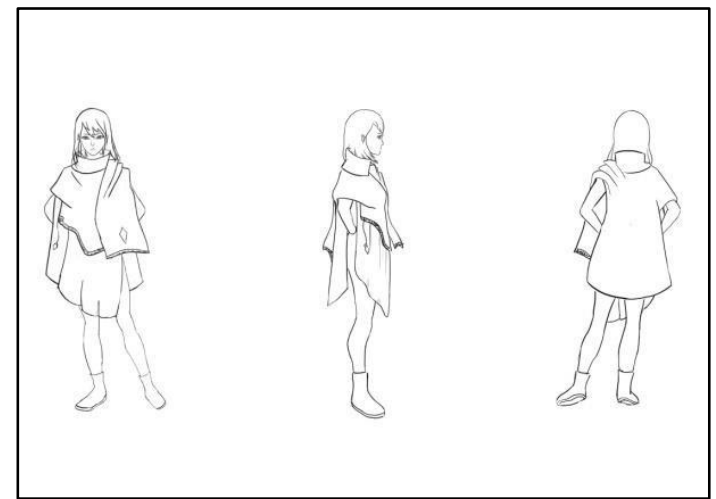

Gambar 20. Rough Sketch Sinta Gambar 23.1

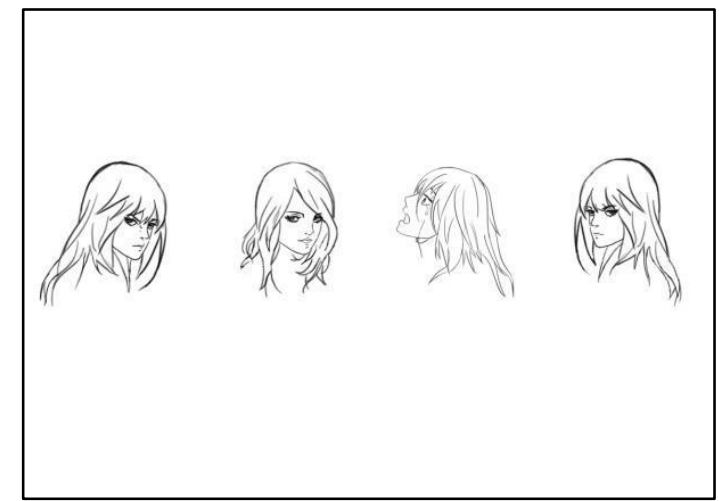

\section{Data Penulis)}

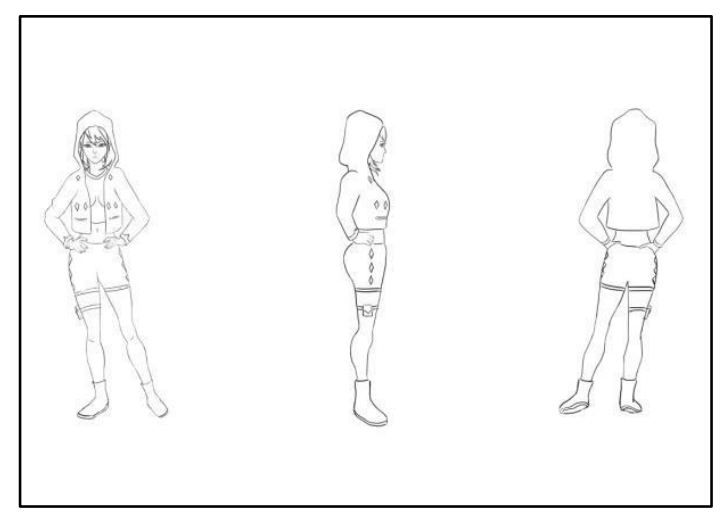

21. Rough Sketch Sinta

(Sumber: Data Penulis)

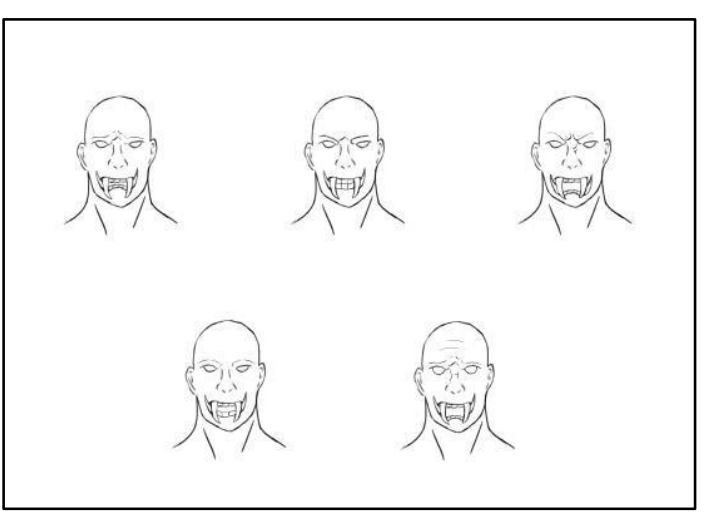

\section{Rough Sketch Rahwana}

4) Rough Sketch Rahwana

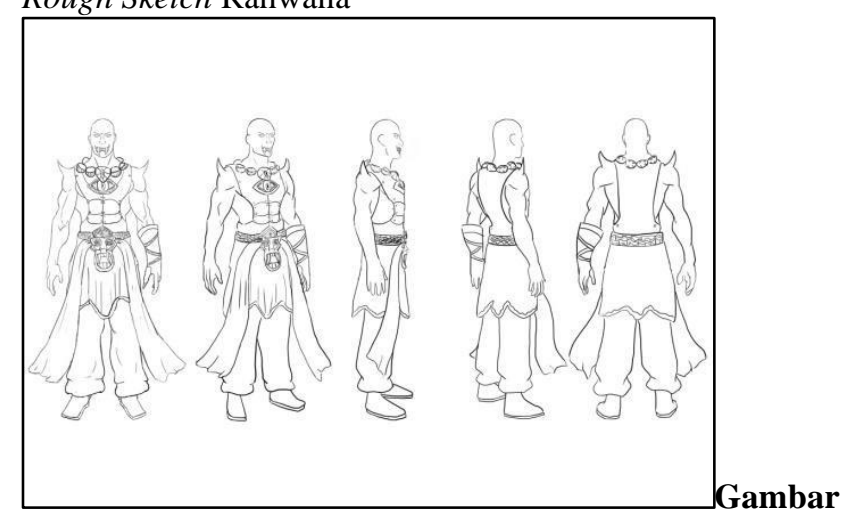

Gambar 24. Rough Sketch Rahwana (Sumber: Data Penulis)

5) Rough Sketch Indrajit

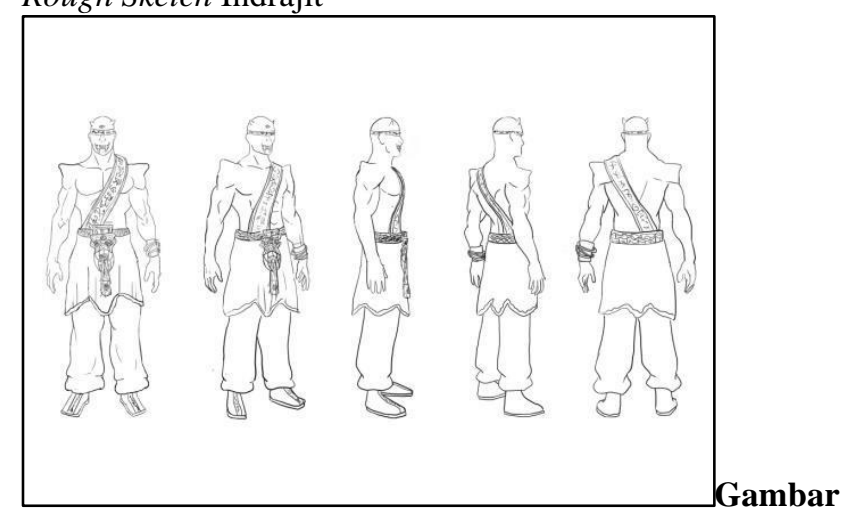


(Sumber: Data Penulis) Gambar 28. Rough Sketch Indrajit

(Sumber: Data Penulis)
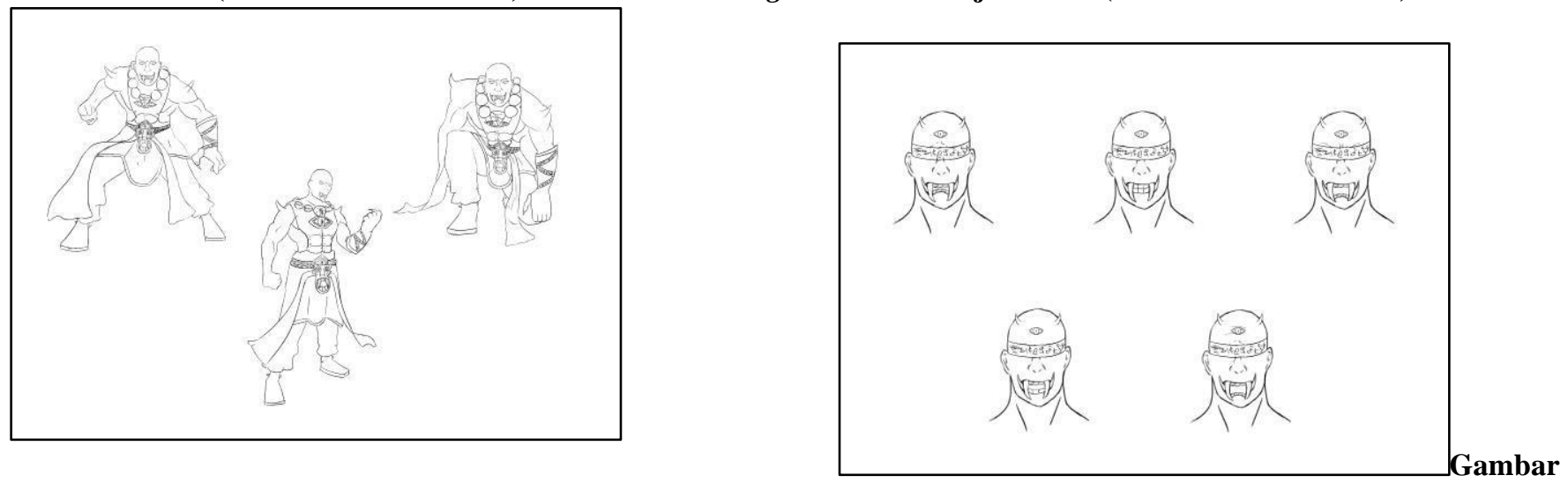

\section{Rough Sketch Rahwana}

(Sumber: Data Penulis) Gambar 29. Rough Sketch Indrajit

(Sumber: Data Penulis)
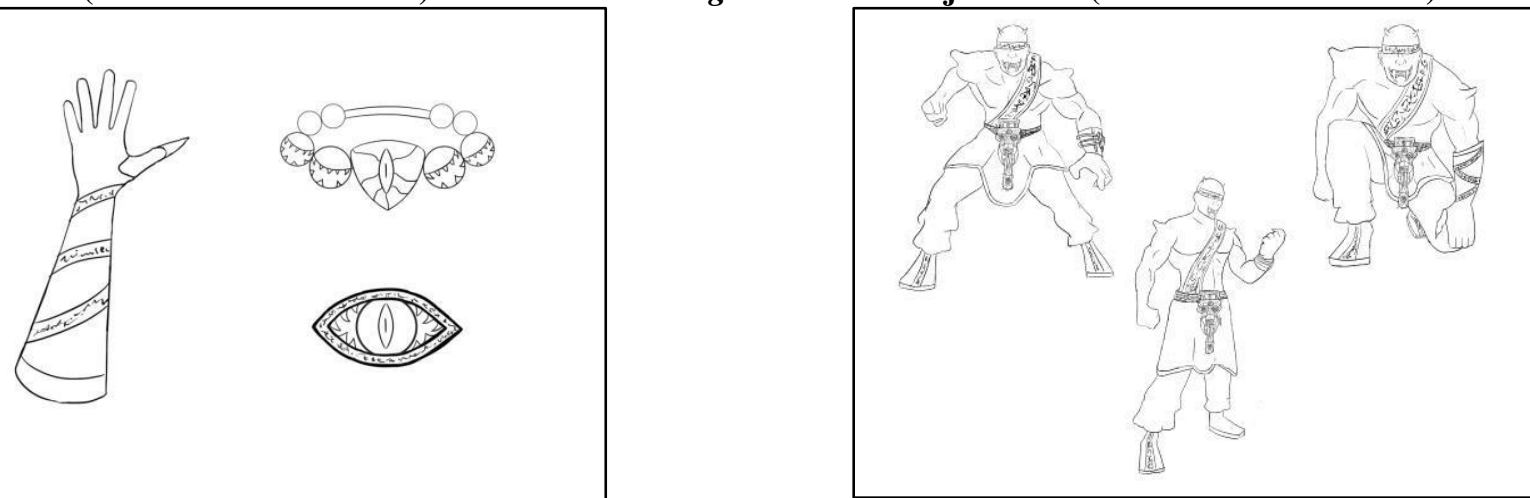

Gambar 27. Rough Sketch Rahwana (Sumber: Data Penulis)

Gambar 30. Rough Sketch Indrajit (Sumber: Data Penulis) 

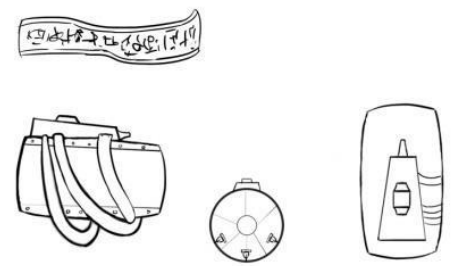
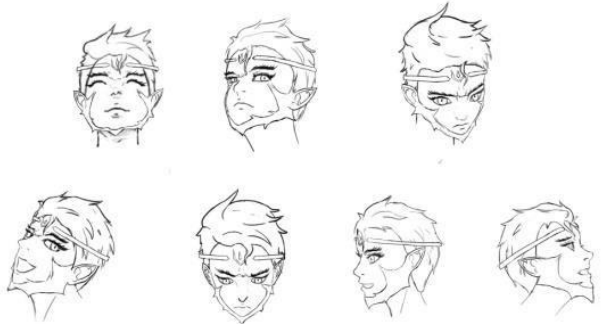

Gambar

\section{Rough Sketch Indrajit}

(Sumber: Data Penulis) Gambar 34. Final Sketch Hanuman

(Sumber: Data Penulis)

Gambar-gambar sebelumnya merupakan hasil desain awal. Setelah melakukan konsultasi maka terdapat beberapa perubahan terhadap beberapa karakter. Pada karakter Hanuman sendiri terdapat perubahan yaitu ditambahkannya jambang pada bagian muka, kemudian simbol yang ada di dahi dimana simbol tersebut merupakan simbol yang ada pada Hanuman, kemudian ditambahkannya pola Poleng pada kain bagian atas dan juga Baik Parang Rusak yang diletakkan di celana.

\section{Final Sketch}

1) Final Sketch Hanuman

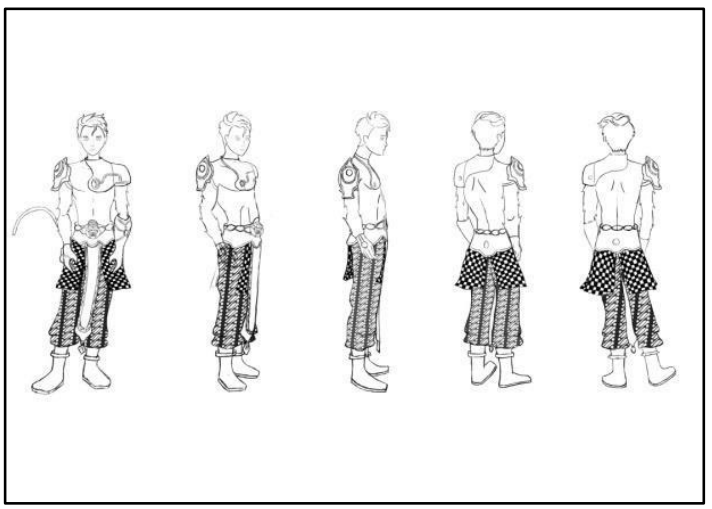

Gambar 32. Final Sketch Hanuman (Sumber: Data Penulis)

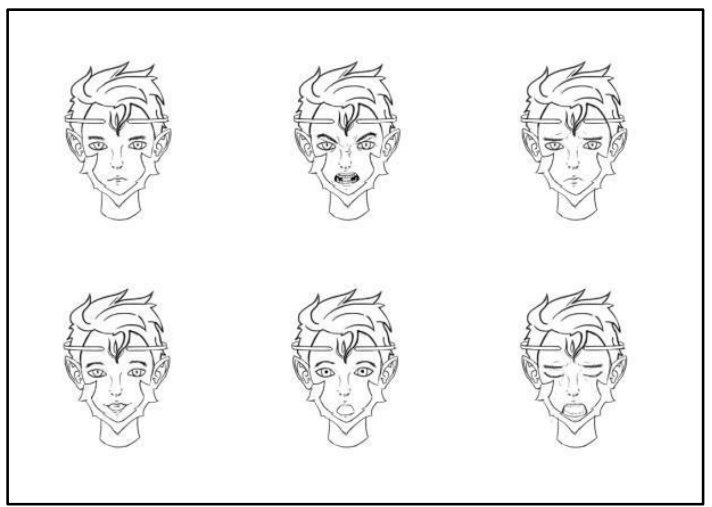

Gambar 33. Final Sketch Hanuman (Sumber: Data Penulis)

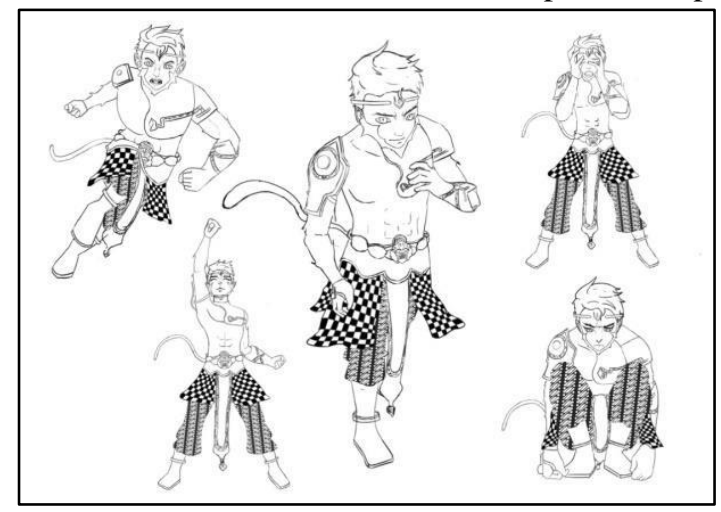

Gambar 35. Final Sketch Hanuman (Sumber: Data Penulis)

2) Final Sketch Rama

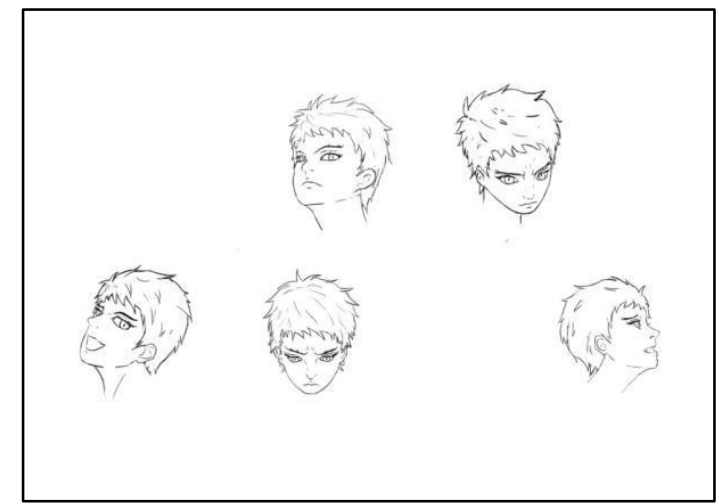

Gambar 36. Final Sketch Rama (Sumber: Data Penulis) 
3)

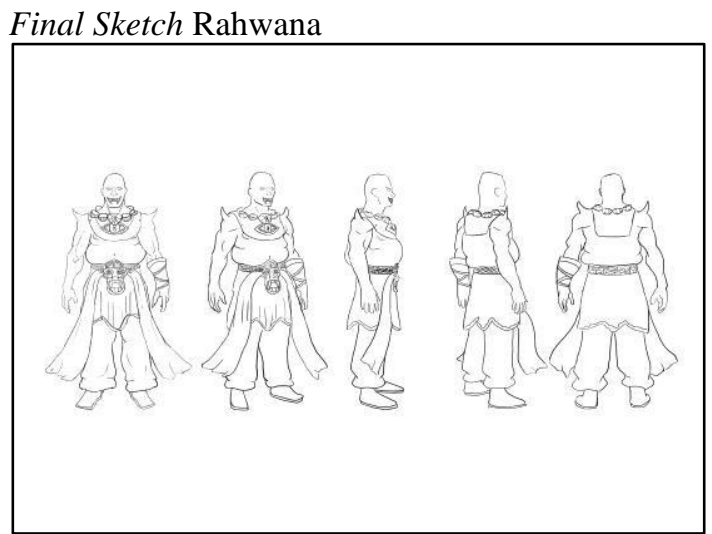

Gambar 37. Final Sketch Rahwana (Sumber: Data Penulis)

4) Final Sketch Indrajit

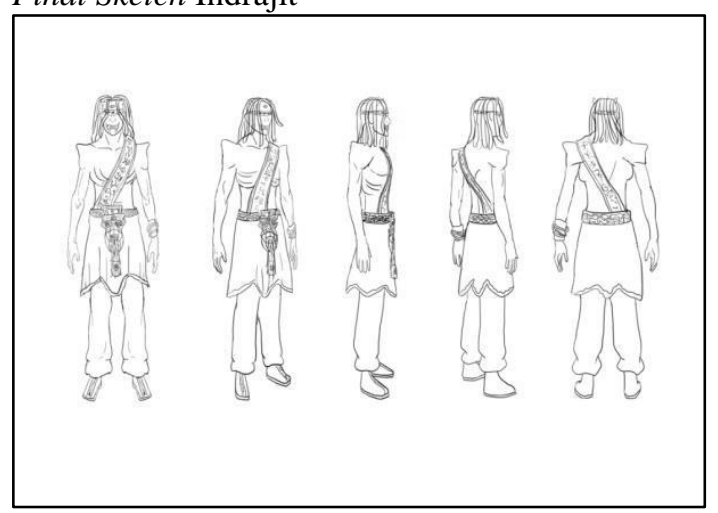

Gambar 38. Final Sketch Indrajit (Sumber: Data Penulis)

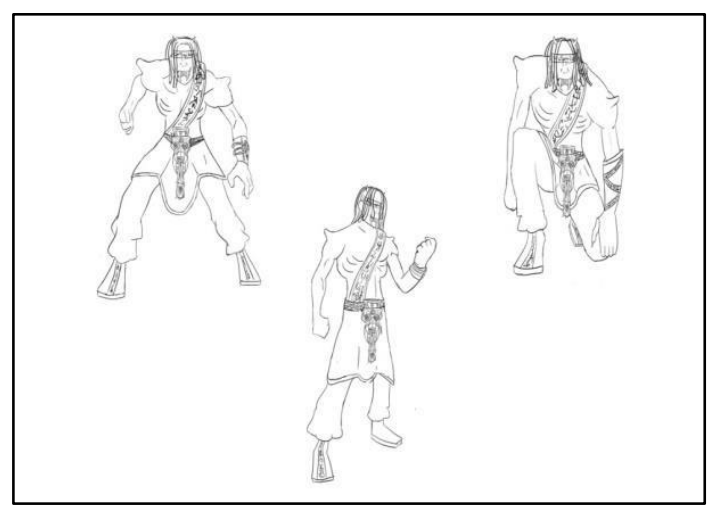

Gambar 39. Final Sketch Indrajit (Sumber: Data Penulis)

\section{Render}

Render adalah pewarnaan yang meliputi gelap terang dari hasil sketch akhir. Berikut merupakan hasil render dari seluruh karakter:

1) Final Render Hanuman

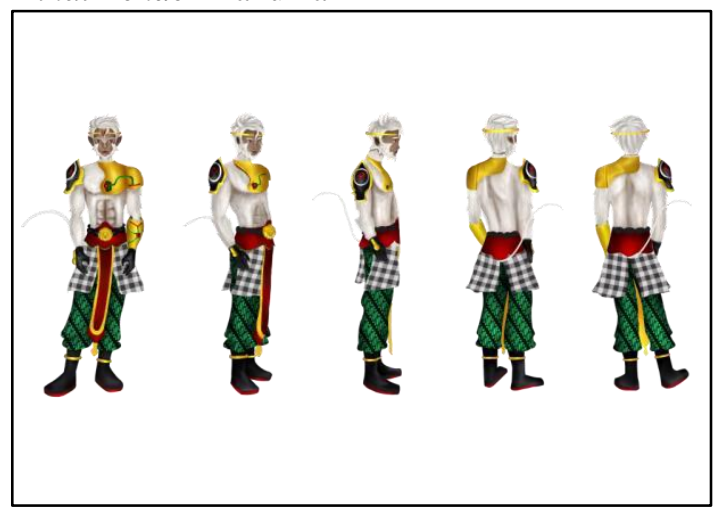

Gambar 40. Final Render Hanuman (Sumber: Data Penulis)

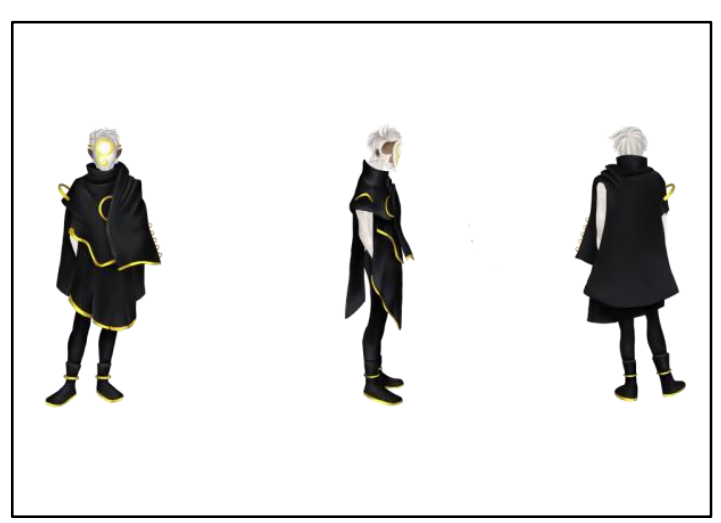

Gambar 41. Final Render Hanuman (Sumber: Data Penulis)

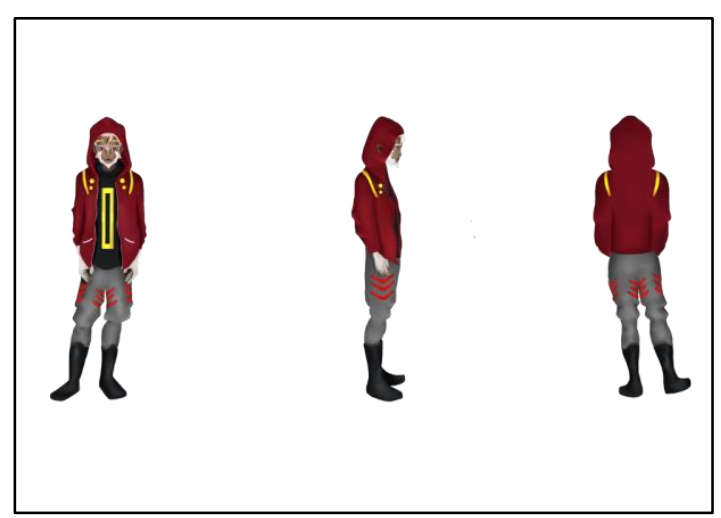

Gambar 42. Final Render Hanuman (Sumber: Data Penulis) 


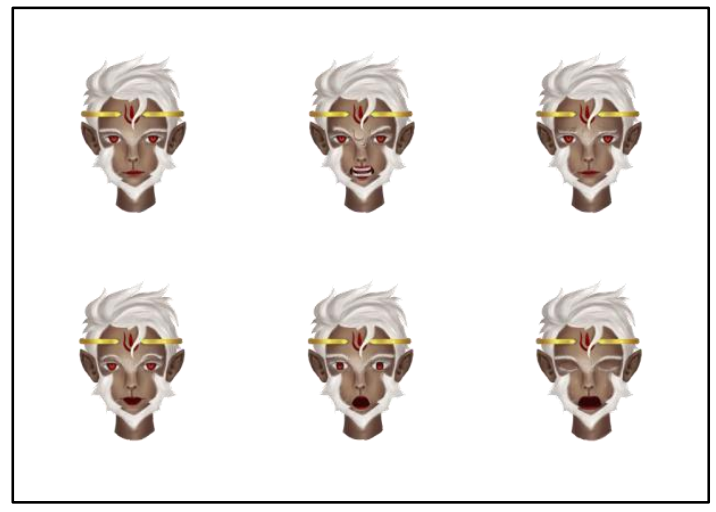

Gambar 43. Final Render

Hanuman (Sumber: Data

Penulis)

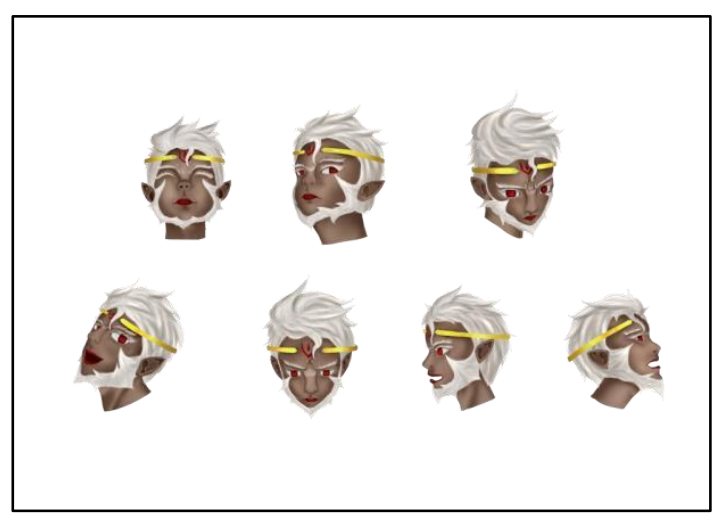

Gambar 44. Final Render

Hanuman (Sumber: Data

Penulis)

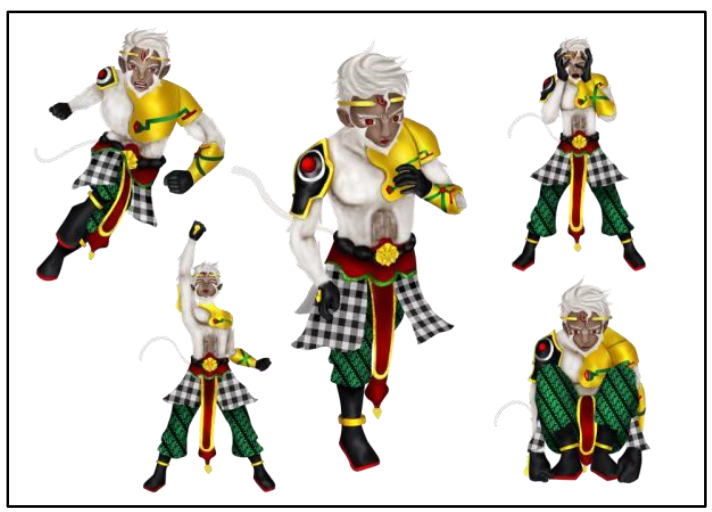

Gambar 45. Final Render

Hanuman (Sumber: Data Penulis)

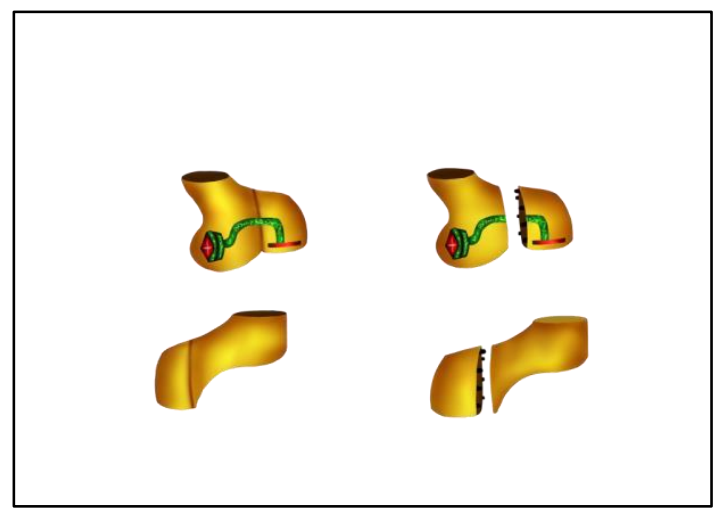

Gambar 46. Final Render Hanuman (Sumber: Data Penulis)

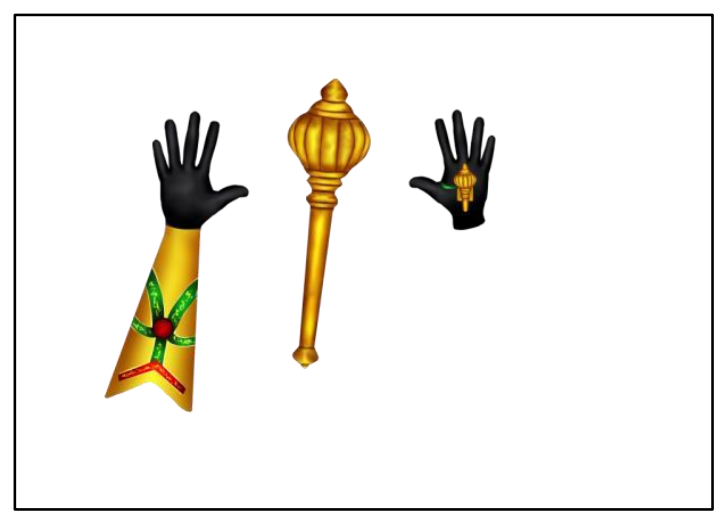

Gambar 47. Final Render Hanuman (Sumber: Data Penulis)

2) Final Render Rama

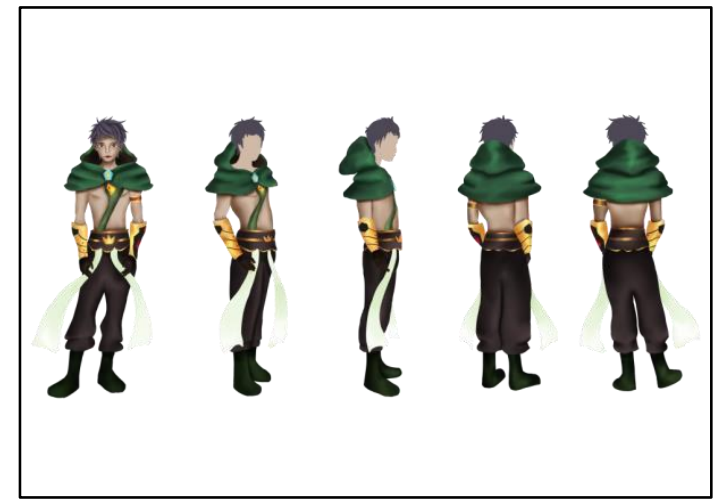

Gambar 48. Final Render Rama (Sumber: Data Penulis) 


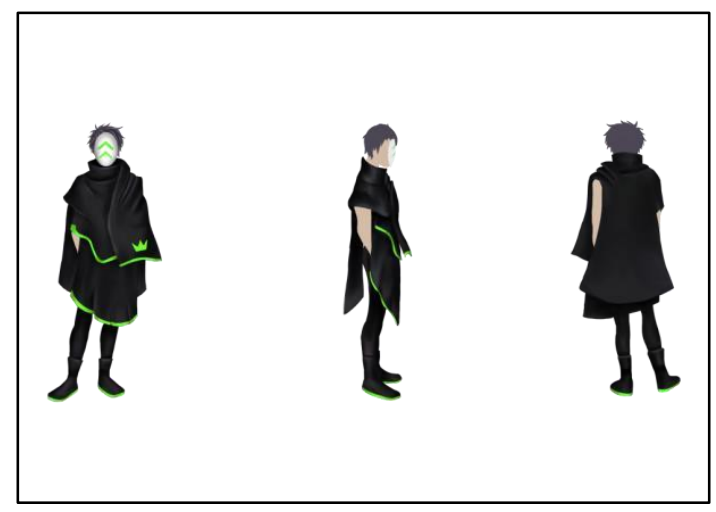

Gambar 49. Final Render Rama

(Sumber: Data Penulis)

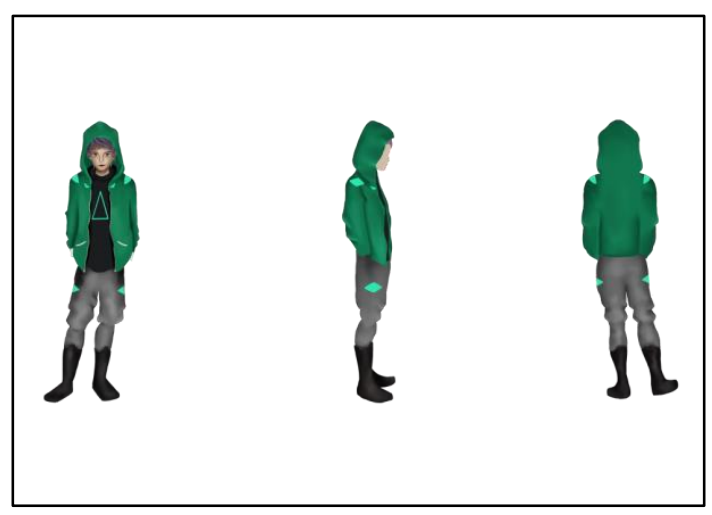

Gambar 50. Final Render Rama

(Sumber: Data Penulis)

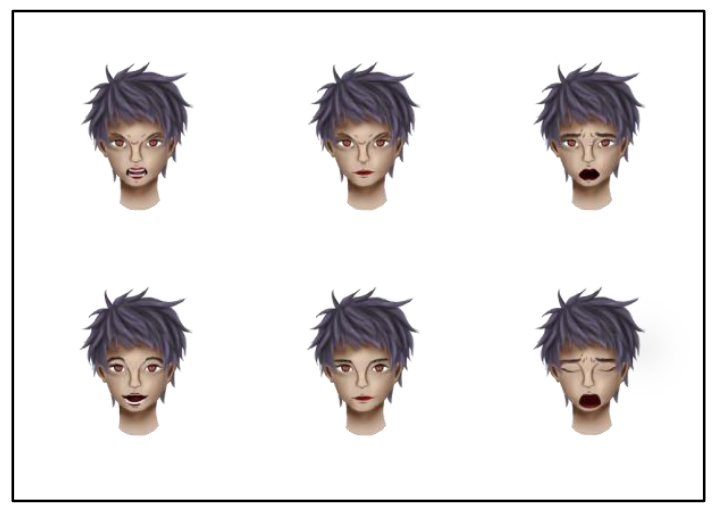

Gambar 51. Final Render Rama

(Sumber: Data Penulis)

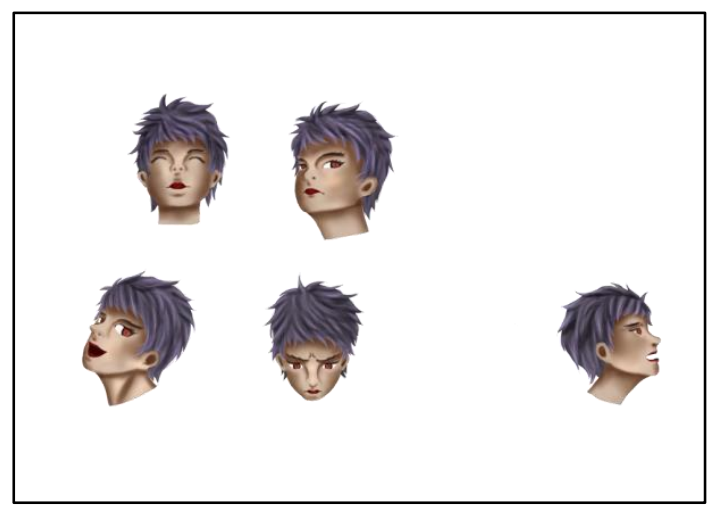

Gambar 52. Final Render Rama

(Sumber: Data Penulis)

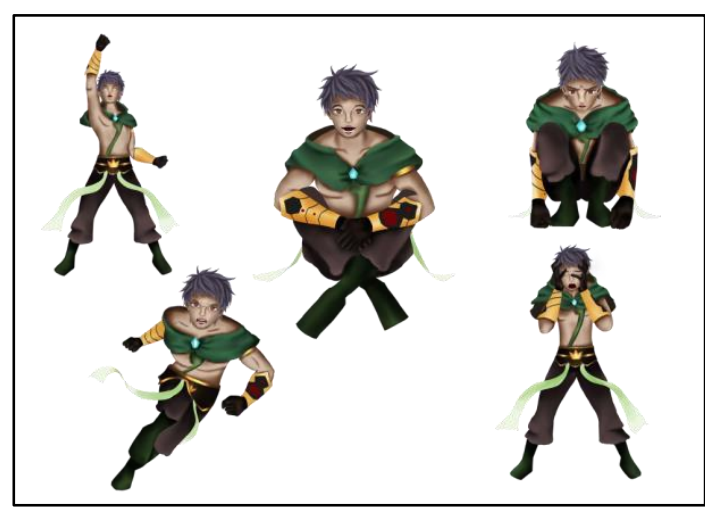

Gambar 53. Final Render Rama

(Sumber: Data Penulis)

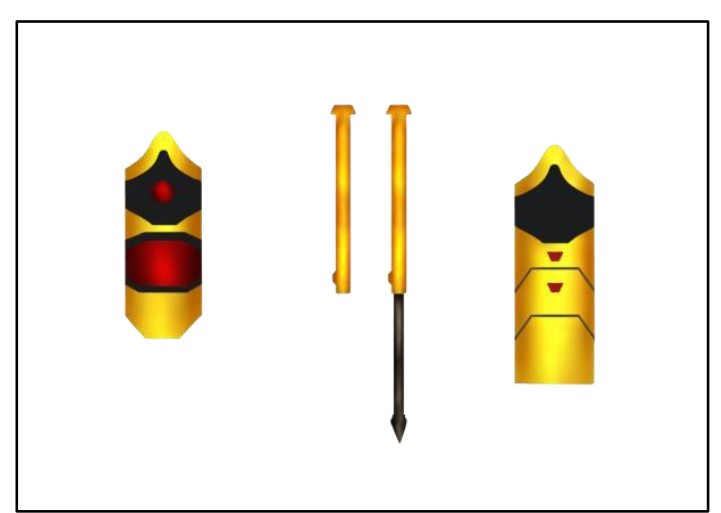

Gambar 54. Final Render Rama (Sumber: Data Penulis) 


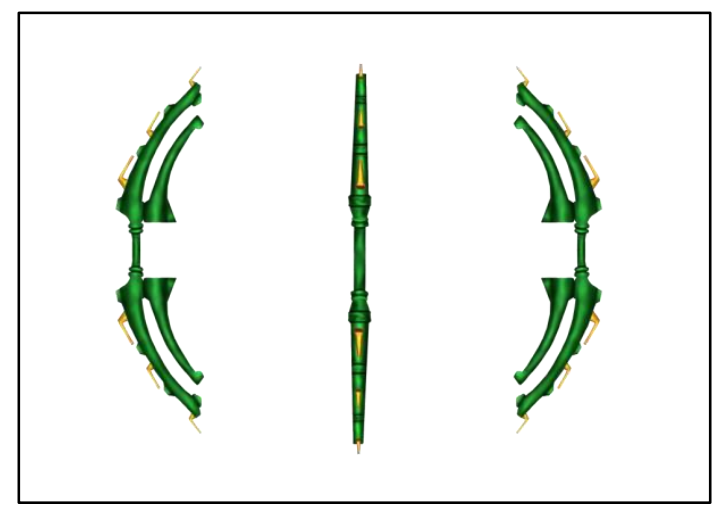

Gambar 55. Final Render Rama (Sumber: Data Penulis)

3) Final Render Sinta

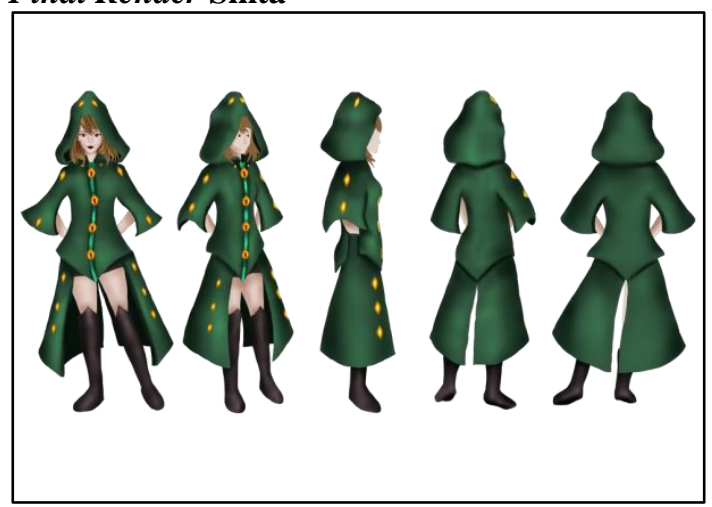

Gambar 56. Final Render Sinta

(Sumber: Data Penulis)

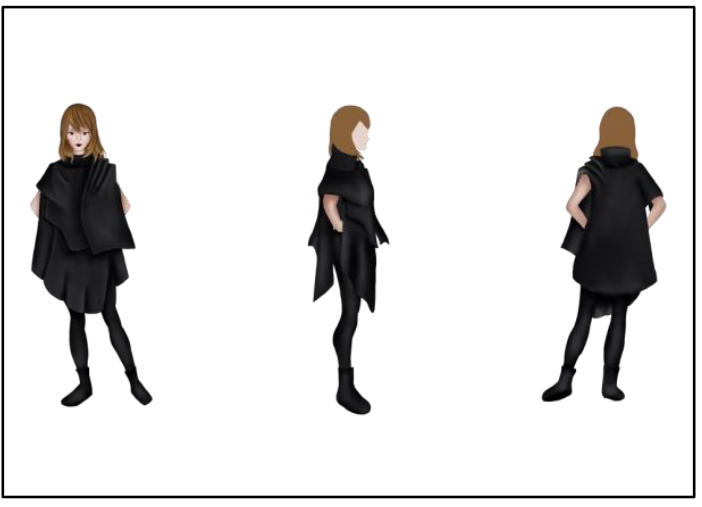

Gambar 57. Final Render Sinta

(Sumber: Data Penulis)

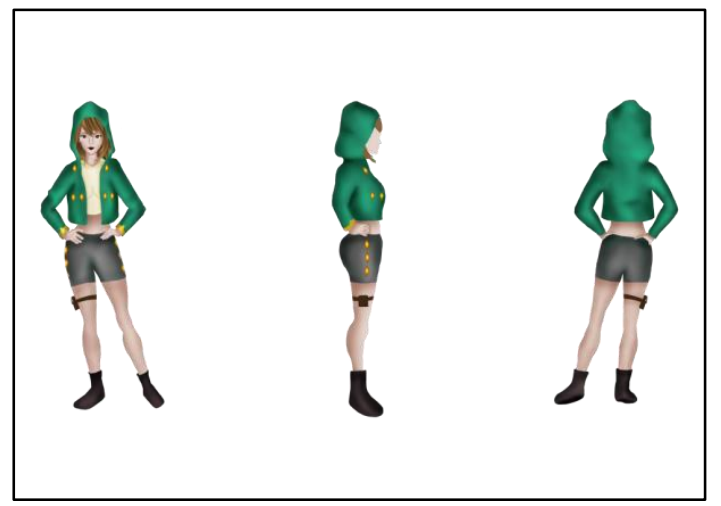

Gambar 58. Final Render Sinta (Sumber: Data Penulis)

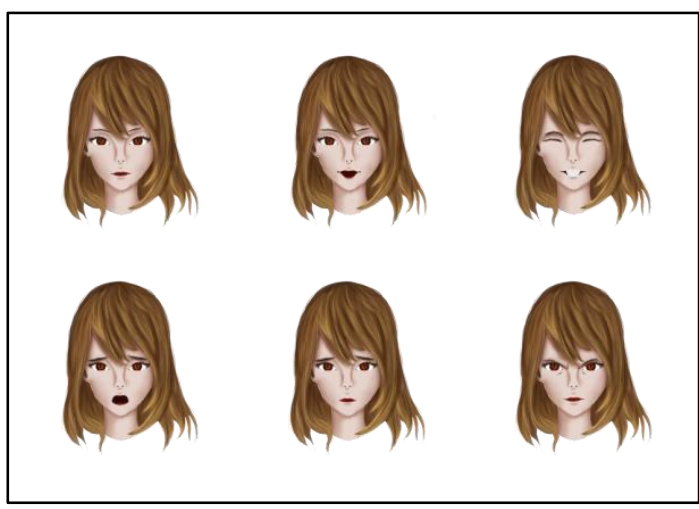

Gambar 59. Final Render Sinta (Sumber: Data Penulis)

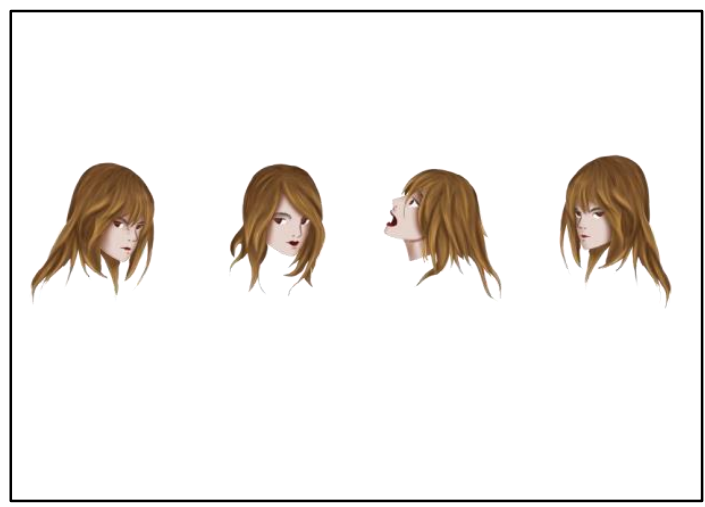

Gambar 60. Final Render Sinta (Sumber: Data Penulis) 


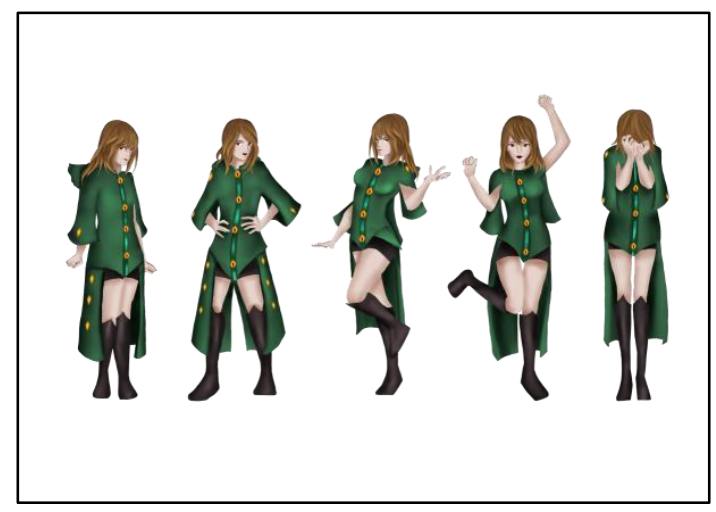

Gambar 61. Final Render Sinta (Sumber: Data Penulis)

4) Final Render Rahwana

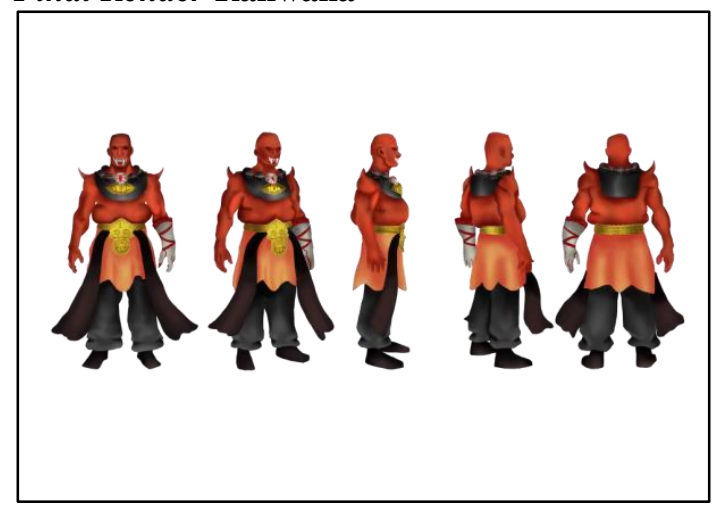

Gambar 62. Final Render Rahwana (Sumber: Data Penulis)

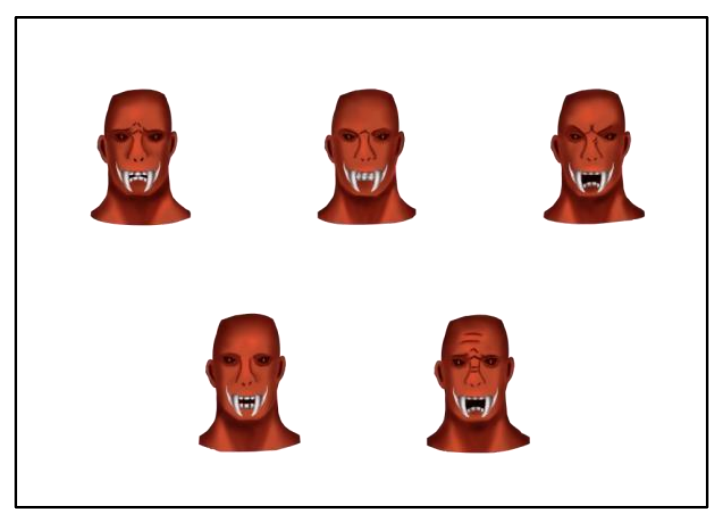

Gambar 63. Final Render Rahwana (Sumber: Data Penulis)

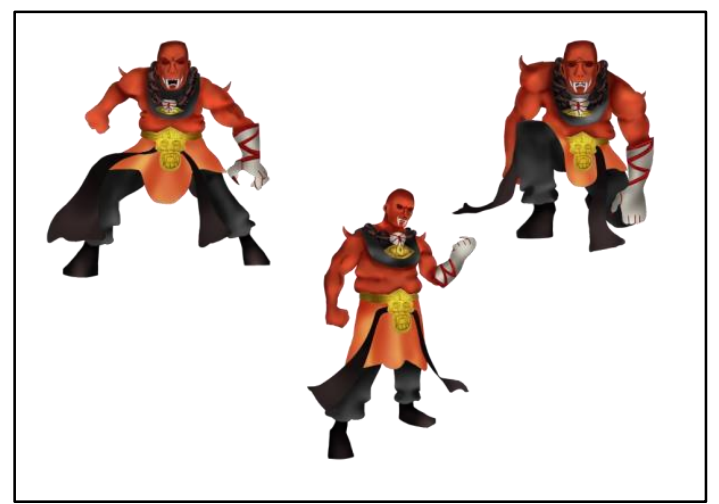

Gambar 64. Final Render Rahwana (Sumber: Data Penulis)

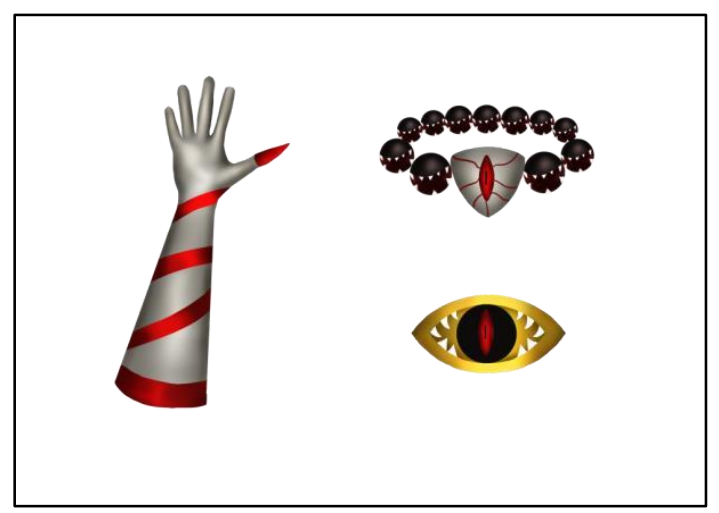

Gambar 65. Final Render Rahwana (Sumber: Data Penulis)

5) Final Render Indrajit

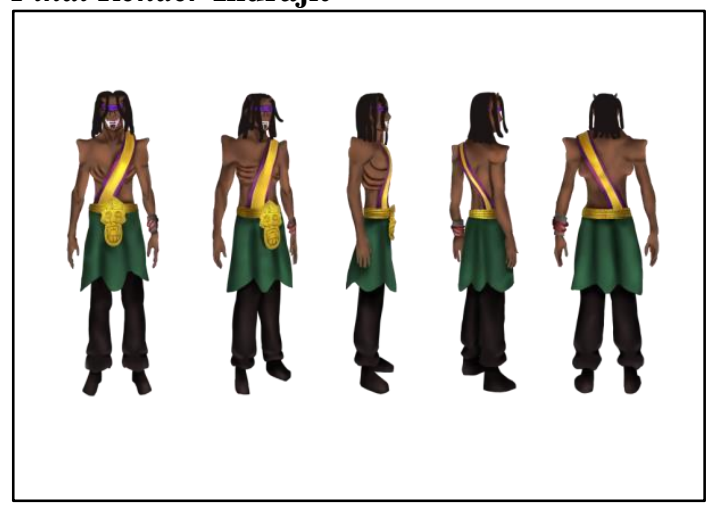

Gambar 66. Final Render Rahwana (Sumber: Data Penulis) 


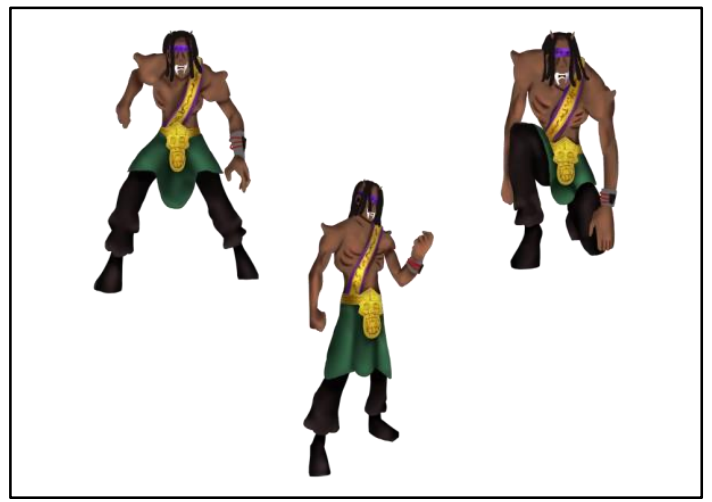

Gambar 67. Final Render

Rahwana (Sumber:

Data Penulis)

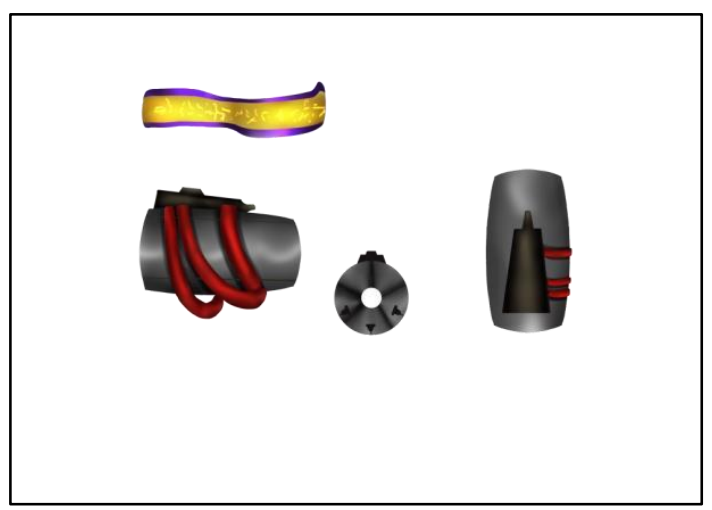

Gambar 68. Final Render

Rahwana (Sumber: Data Penulis)

\section{KESIMPULAN}

Semakin berkembangnya waktu dan juga jaman mengakibatkan budaya-budaya asli Indonesia mulai dilupakan. Hal ini dapat dibuktikan dengan mulai susahnya ditemukan budaya-budaya asli Indonesia disekitar kita terutama di kota-kota karena masyarakat milenial menganggap bahwa budaya-budaya tersebut sudah kuno atau juga kolot. Salah satu yang susah ditemukan yaitu epos atau folklor. Folklor merupakan salah satu budaya yang ada di Indonesia dimana merupakan dimensi masa lampau yang bisa dijadikan sebagai media pembelajaran untuk melangkah kedepannya.

Pengenalan folklor atau budaya Indonesia ini sendiri juga penting terlebih untuk generasi milenial agar tidak lupa akan budaya-budayanya sendiri. Salah satu folklor yang ada di Indonesia yaitu Ramayana. Ramayana sendiri merupakan folklor yang berasal dari India, dan kemudian mengalami akulturasi di Indonesia. Folklor Ramayana mempunyai nilai-nilai kehidupan yang baik yang dapat dijadikan sebagai acuan atau teladan di kehidupan yang nyata terlebih untuk generasi milenial.

Proses perancangan atau redesain ini menerapkan metode pengumpulan data yang berisi tentang observasi dan studi kepustakaan. Observasi sendiri melihat ke masyarakat tentang hal atau karakter seperti apa yang mereka sukai yang kemudian ditambah dengan studi kepustakaan. Dalam studi kepustakaan ini mengumpulkan data-data terkait dengan karakter-karakter asli dalam folklor Ramayana dan juga tentang pembuatan sebuah karakter. Studi kepustakaan terkait pembuatan karakter ini, kemudian dijabarkan ke dalam beberapa tahapan yaitu menentukan karakter jenis apa yang dibuat, kemudian mengisi form yang berupa datadata pendukung karakter.

Hasil akhir dari perancangan ini berupa artbook, yang berisikan tentang fivepoint turn around, character action poses, facial expressions, kemudian media sosial yaitu instagram, serta media pendukung seperti totebag, kaos dan juga topi serta 5 buah concept art.

\section{DAFTAR PUSTAKA}

Krawczyk, N. 2006, Game Development Essentials: Game Story \& Character Development, Thompson Delmar Learning, Clifton Park. New York

Adams, E. 2007. Fundamentals of Game Design. New Riders, Thousand Oaks. California

Tillman, B. 2011, Creative Character Design, Focal Press. Oxford, USA

Tofani, A. 2013, Mengenal Wayang Kulit Purwa, Pustaka Agung Harapan, Surabaya, Indonesia

Gopalachari. 2008, Ramayana, IRCiSoD, Jogjakarta. Indonesia

Sindusastra, RNg. 1930. Arjunasasrabau. Balai Pustaka, Jakarta. Indonesia

Ruyattman, M. 2013, Perancangan Buku Panduan Membuat Desain Karakter Fiksi Dua Dimensi secara Digital, Jurnal DKV Adiwarna, Universitas Kristen Petra, 1 Nirwana, A. 2018, Desain Karakter Jaka Kembang Kuning: Sebuah ReInterpretasi Tokoh Wayang Beber Pacitan ke Dalam Bentuk Populer, Prosiding Seminar Nasional FSRD - ISI Denpasar

Rahman, A. 2020, Perancangan Artbook Visual Karakter Kaba Anggun Nan Tongga, Jurnal Desain

Komunikasi Visual jurusan Seni Rupa, Universitas Negeri Padang

Yazid, M. 2018, Perancangan Desain Karakter Urang Bunian Dalam Budaya Minangkabau Melalui Media Art Book, DEKAVE: Jurnal Desain Komunikasi Visual, 7

Haryadi, T., dan Khamadi. 2014, Perancangan Model Wujud Visual Tokoh Pewayangan dalam

Pembentukan Identitas dan Watak Tokoh Sebagai Acuan Desain Karakter dalam Karya DKV, Jurnal Dekave, 7; 56-77

Kim, Y. 2004, The Structural Analysis of the Hindi and South-East Asian Versions of the Indian Epic, the 
Ramayana: With Particular Reference to Hindi, Javanese, and Thai Versions, Antropologi Indonesia, 75: 101-114

Soekimin. 1990, Hanuman dalam Karya Sastra Jawa, Cakrawala Pendidikan, Jurnal Ilmiah Pendidikan,

1: 12-31

Redaksi. 2017, „Kisah Ramayana: Mitos atau Sejarah?ee Timur Jawa, diakses pada tanggal 15 Oktober 2018,

<http://www.timurjawa.com/2017/01/06/ kisahramayana-mitos-atau-sejarah/>

Indonesia Student. 2017. „Pengertian Folklore Menurut Para Ahli dan Contohnya Lengkap" Indonesia Students, diakses ada tanggal 15 Oktober 2018,

$<$ http://www.indonesiastudents.com/peng ertianfolklore-menurut-para-ahli-dancontohnya/>

Rao, D.H. dan Murthy, K.M.K. 1998-2007.

„Sundarakanda ${ }^{e e}$, diakses pada tanggal 15 Oktober

2018, <http://sejarahindonesia.perpustakaan.web.id/id3/44632

9/Sundarakanda_35262_sejarahindonesiaperpustakaan.html>

Cakiel, H. 2018. „Hanoman: Ciri Fisik, Kisah Singkat dan

Watak Sifat Karakteristik ${ }^{\text {ee }}$ Jagad.ig, diakses pada tanggal 15 Oktober 2018, <https://jagad.id/wayanghanoman/>

Nisa, H. 2017. „Pengertian Tokoh dan Penokohan Menurut Para Ahlie TekoNeko, diakses pada tanggal 15 Oktober 2018, <https://tekoneko.net/pengertiantokoh/>

Stein, F.N. 2017. „Arti Kata “Figur” Makna Pengertian dan Definisie ArtiKBBI, diakses pada tanggal 15 Oktober 2018, <https://artikbbi.com/figur/>

Pemajuan Kebudayaan, 2018. Undang-undang, diakses pada tanggal 4

Maret 2020,

$<$ http://pemajuankebudayaan.id/undangundang/> 